\title{
Water level, vegetation composition, and plant productivity explain greenhouse gas fluxes in temperate cutover fens after inundation
}

\author{
Merten Minke ${ }^{1,5}$, Jürgen Augustin ${ }^{2}$, Andrei Burlo ${ }^{3}$, Tatsiana Yarmashuk ${ }^{4}$, Hanna Chuvashova ${ }^{3}$, Annett Thiele ${ }^{5,6}$, \\ Annette Freibauer ${ }^{1}$, Vitalij Tikhonov ${ }^{3}$, and Mathias Hoffmann ${ }^{7}$ \\ ${ }^{1}$ Thünen Institute of Climate-Smart Agriculture, Braunschweig, Germany \\ ${ }^{2}$ Institute for Landscape Biogeochemistry, ZALF e.V., Müncheberg, Germany \\ ${ }^{3}$ Scientific and Practical Centre of the National Academy of Sciences of Belarus for Biological Resources, Minsk, Belarus \\ ${ }^{4}$ Institute for Nature Management of the National Academy of Sciences of Belarus, Minsk, Belarus \\ ${ }^{5}$ Institute of Botany and Landscape Ecology, Ernst-Moritz-Arndt University, Greifswald, Germany \\ ${ }^{6}$ Michael Succow Foundation, Greifswald, Germany \\ ${ }^{7}$ Institute of Soil Landscape Research, ZALF e.V., Müncheberg, Germany
}

Correspondence to: Merten Minke (merten.minke@ti.bund.de)

Received: 10 September 2015 - Published in Biogeosciences Discuss.: 29 October 2015

Revised: 2 April 2016 - Accepted: 5 June 2016 - Published: 8 July 2016

\begin{abstract}
Peat extraction leaves a land surface with a strong relief of deep cutover areas and higher ridges. Rewetting inundates the deep parts, while less deeply extracted zones remain at or above the water level. In temperate fens the flooded areas are colonized by helophytes such as Eriophorum angustifolium, Carex spp., Typha latifolia or Phragmites australis dependent on water depth. Reeds of Typha and Phragmites are reported as large sources of methane, but data on net $\mathrm{CO}_{2}$ uptake are contradictory for Typha and rare for Phragmites. Here, we analyze the effect of vegetation, water level and nutrient conditions on greenhouse gas (GHG) emissions for representative vegetation types along water level gradients at two rewetted cutover fens (mesotrophic and eutrophic) in Belarus. Greenhouse gas emissions were measured campaign-wise with manual chambers every 2 to 4 weeks for 2 years and interpolated by modelling.

All sites had negligible nitrous oxide exchange rates. Most sites were carbon sinks and small GHG sources. Methane emissions generally increased with net ecosystem $\mathrm{CO}_{2}$ uptake. Mesotrophic small sedge reeds with water table around the land surface were small GHG sources in the range of 2.3 to $4.2 \mathrm{tCO}_{2}$ eq. ha ${ }^{-1} \mathrm{yr}^{-1}$. Eutrophic tall sedge - Typha latifolia reeds on newly formed floating mats were substantial net GHG emitters in the range of 25.1 to $39.1 \mathrm{tCO}_{2}$ eq. ha ${ }^{-1} \mathrm{yr}$. They represent transient vegetation stages. Phragmites reeds ranged between -1.7 to
\end{abstract}

4.2 $\mathrm{tCO}_{2}$ eq. ha ${ }^{-1} \mathrm{yr}^{-1}$ with an overall mean GHG emission of $1.3 \mathrm{tCO}_{2}$ eq. ha $\mathrm{Cr}^{-1} \mathrm{yr}^{-1}$. The annual $\mathrm{CO}_{2}$ balance was best explained by vegetation biomass, which includes the role of vegetation composition and species. Methane emissions were obviously driven by biological activity of vegetation and soil organisms.

Shallow flooding of cutover temperate fens is a suitable measure to arrive at low GHG emissions. Phragmites australis establishment should be promoted in deeper flooded areas and will lead to moderate, but variable GHG emissions or even occasional sinks. The risk of large GHG emissions is higher for eutrophic than mesotrophic peatlands. Nevertheless, flooding of eutrophic temperate fens still represents a safe GHG mitigation option because even the hotspot of our study, the floating tall sedge - Typha latifolia reeds, did not exceed the typical range of GHG emissions from drained fen grasslands and the spatially dominant Phragmites australis reed emitted by far less GHG than drained fens.

\section{Introduction}

Cutover peatlands represent about 10 percent of all drained peatlands outside the tropics with the main share in the Nordic countries and Eastern Europe (Joosten and Clarke, 2002). Since the 1990 s restoration of cutaway peatlands was 
conducted especially in Canada, Finland, Sweden and Ireland. Similar projects in Eastern Europe started later, but already cover vast areas. 42000 ha of degraded peatlands were restored in Belarus since 2007 and about 80000 ha since 2010 in the European part of Russia, aiming to decrease GHG emissions from microbial peat oxidation and peat fire incidents (Tanneberger and Wichtmann, 2011; Wetlands International, 2015).

A large proportion of the peatlands that have been rewetted or are available for rewetting in Russia and Belarus are abandoned cutover fens (Minayeva et al., 2009; Tanovitskaya and Kozulin, 2011). Rewetting of such sites creates a mosaic of wet and flooded zones and elevated drier parts, and results in rapid vegetation changes (Kozulin et al., 2010; Thiele et al., 2011). At sites with the water level close to surface species like Eriophorum angustifolium, Carex vesicaria and Lythrum salicaria establish within a few years, or, under more nutrient rich conditions, Calamagrostis canescens, Lysimachia thyrsiflora, Carex elata, and Salix. At flooded areas with standing water depths of more than $20 \mathrm{~cm}$ mainly Phragmites australis emerges, whereas water levels above $30 \mathrm{~cm}$ in the medium term only result in the establishment of submerse and floating plants (Kozulin et al., 2010; Thiele et al., 2011).

Studies from rewetted cutover boreal peatlands and temperate bogs show that methane and carbon dioxide emissions are strongly related to water level, vegetation, and meteorological conditions (Tuittila et al., 1999, 2000; Drösler, 2005; Yli-Petäys et al., 2007; Soini et al., 2010; Samaritani et al., 2011; Strack and Zuback, 2013; Wilson et al., 2013; Beyer and Höper, 2015). For rewetting it is frequently recommended to raise the water level throughout the year to close to the surface and to avoid inundation in order to promote the establishment of peat forming vegetation and to prevent high methane emissions (Drösler et al., 2008; Couwenberg et al., 2008, 2011; Joosten et al., 2012). Such conditions have been proven optimal for bog restoration (Beyer and Höper, 2015), but their feasibility for fens has been questioned (Koebsch et al., 2013; Zak et al., 2015). In practice, fens are often rewetted by shallow flooding.

So far, complete GHG balances are not available for rewetted temperate cutover fens. Such fens differ from those in the above cited studies in particular by the massive establishment of Typha and Phragmites australis in shallow water, i.e. of species that are potentially strong pathways of methane (Kim et al., 1998; Brix et al., 2001; Whiting and Chanton, 2001; Kankaala et al., 2004; Hendriks et al., 2007; Chu et al., 2015; Knox et al., 2015; Strachan et al., 2015). Whereas earlier studies indicate that the radiative forcing of such methane emissions may be compensated for by the simultaneous very strong net $\mathrm{CO}_{2}$ uptake (Brix et al., 2001; Whiting and Chanton, 2001), recent observations described Typha dominated wetlands as often only weak $\mathrm{CO}_{2}$ sinks (Rocha and Goulden, 2008; Chu et al., 2015; Strachan et al., 2015; but cf. Knox et al., 2015). Moreover, submerse and floating plants that are promoted by deep flooding have much higher methane production potential than emergent species (Kankaala et al., 2003; Zak et al., 2015).

This study aims to quantify GHG emissions from inundated temperate cutover fens recolonized by wetland plants. We measured for 2 years the $\mathrm{CO}_{2}, \mathrm{CH}_{4}$, and $\mathrm{N}_{2} \mathrm{O}$ emissions from Phragmites australis communities and other representative vegetation types along water level gradients in a mesotrophic and a eutrophic rewetted cutover fen in Belarus. We hypothesize the following.

i. All sites are net $\mathrm{CO}_{2}$ sinks: peat loss by oxidation has stopped after rewetting. The net $\mathrm{CO}_{2}$ sink increases with nutrient status, the productivity of the vegetation and peaks under shallow inundation.

ii. Methane emissions increase with the productivity of the vegetation and peak under shallow inundation.

iii. The net GHG balance is near neutral when water levels are close to surface because $\mathrm{CH}_{4}$ emissions are balanced by the net $\mathrm{CO}_{2}$ sink. The net GHG balance turns into a source when sites are continuously flooded because the global warming by $\mathrm{CH}_{4}$ emissions exceeds the net $\mathrm{CO}_{2}$ sink.

\section{Materials and methods}

\subsection{Study sites}

Greenhouse gas fluxes were measured at two sites in Belarus (Fig. 1) with a temperate continental climate with fully humid conditions and warm summers (Dfb after Köppen, 1936; cf. Kottek et al., 2006). Both sites have been subject to peat extraction, but differ with respect to time since rewetting, water depth, peat characteristics and nutrient status, vegetation, and regional climate.

"Barcianicha" $\left(54.10^{\circ} \mathrm{N} ; 26.29^{\circ} \mathrm{E}\right)$ is located in central Belarus on an alluvial plain between the rivers Al'šanka and Zahodniaia ("western") Biarėzina and predominantly fed by groundwater discharge (Maksimenkov et al., 2006). In 1990 about 190 ha of Barcianicha were drained and from 1992 to 1995 peat was extracted by milling over an area of 150 ha to a remaining peat depth of about $80 \mathrm{~cm}$. After abandonment ditches were closed with earth dams and water level was raised on $60 \%$ of the area, allowing wetland species like Phragmites australis, Carex rostrata and Eriophorum angustifolium to establish (Maksimenkov et al., 2006). Strong water level amplitudes between summer and winter were stabilized in 2007 by weirs and overflow dams. In 2010 most of the area had water levels at or slightly above the surface throughout the year. Tall reeds, dominated by Phragmites australis of up to $2 \mathrm{~m}$ height, covered the area. Three GHG monitoring sites were installed along a water level gradient, including the small sedge reeds Eriophorum angustifolium-Carex rostrata (further indicated as BA 


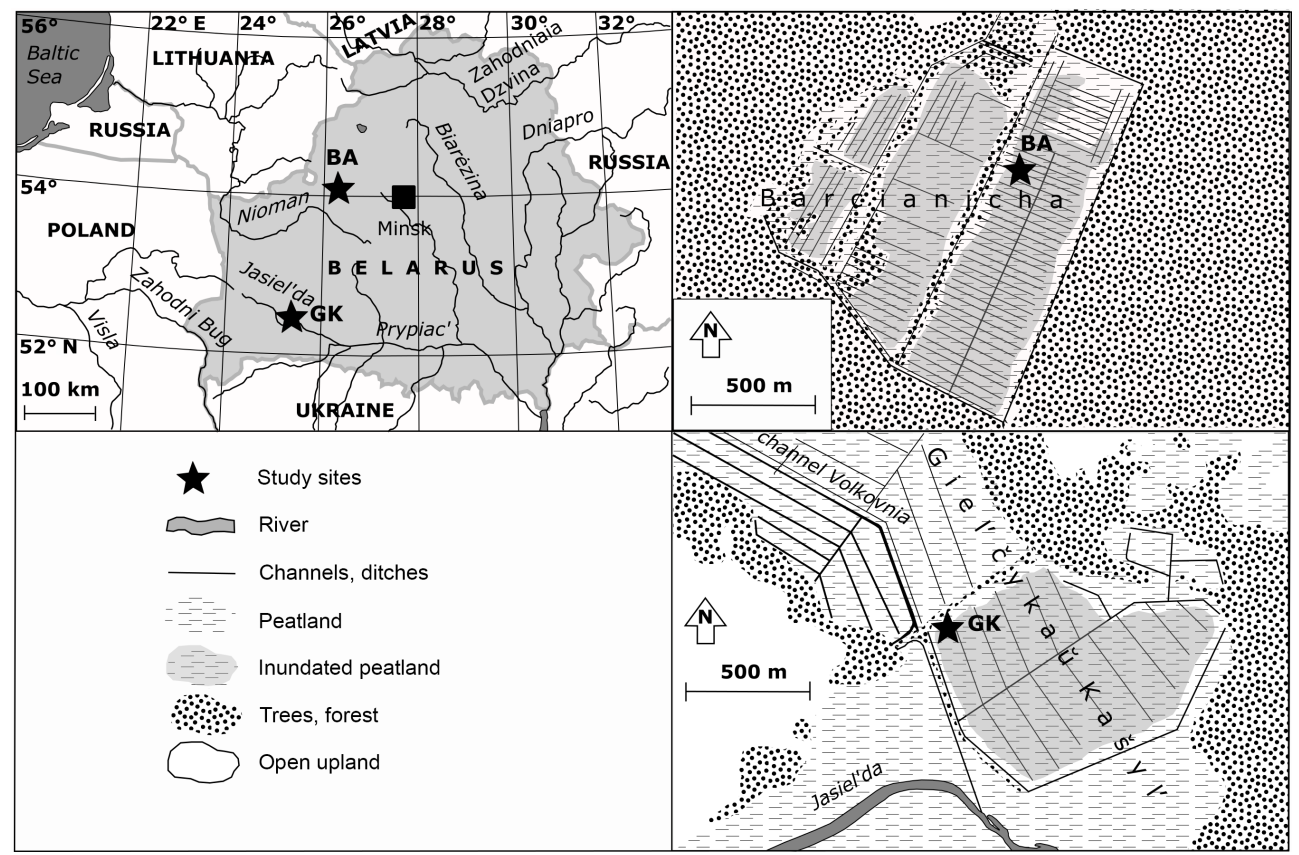

Figure 1. Location of the study sites.

Eriophorum-Carex) and Carex rostrata-Equisetum fluviatile (BA Carex-Equisetum) at $15 \mathrm{~m}$ distance, and a Phragmites australis-Carex rostrata reed (BA Phragmites-Carex) at another $30 \mathrm{~m}$ distance (Appendix Table A1).

The second peatland, "Giel'cykaŭ Kašyl"" $\left(52.38^{\circ} \mathrm{N}\right.$; $25.21^{\circ} \mathrm{E}$ ), forms part of the "Bierastaviec" fen and is situated on the left bank of Jasiel'da River. It belongs to the Ramsar site "Sporaŭski zakaznik" and was drained in 1975 (Kadastrovyj spravochnik, 1979). More than $1 \mathrm{~m}$ of peat remained after peat extraction and grassland was established. But as the area proved to be unsuited for hay production, the pumping station was turned off in 1985. The area was flooded by the Jasiel'da, which is connected with Giel'cykaŭ Kašyl' by a $300 \mathrm{~m}$-long channel. During the vegetation period the area receives additional water pumped out of an adjacent drained fen. Phragmites australis of $3 \mathrm{~m}$ height dominates the area, which is flooded up to $1 \mathrm{~m}$ above the surface. A $30-80 \mathrm{~m}$ wide swampy zone along the edges is formed by Typha latifolia, T. angustifolia, and tussocks of Carex elata and C. vesicaria floating on up to $1 \mathrm{~m}$ of water. GHG monitoring was performed in the floating tall sedge reeds at two sites: a Carex elata-Lysimachia thyrsiflora site (GK Carex-Lysimachia), and a Typha latifolia-Hydrocharis morsus-ranae site (GK Typha-Hydrocharis; Table A1), at $3 \mathrm{~m}$ distance from each other. The third Phragmites australis-Lemna trisulca site (GK Phragmites-Lemna) was situated $20 \mathrm{~m}$ from the first two sites in the deeper inundated main area, separated from the swampy zone by a flooded ditch.

\subsection{Site characteristics}

Each site was split into three plots. Peat depth, stratigraphy and degree of decomposition after Von Post (AG Boden, 2005) were determined for each site using a chamber corer (50 $\mathrm{cm}$ long, $5 \mathrm{~cm}$ diameter). One mixed surface peat sample $(0-5 \mathrm{~cm})$ from each plot was analysed for total carbon (C) and total N (Vario EL III, Germany), and three samples per plot for $\mathrm{pH}$ (Hanna Combo HI 98130, calibrated with 7.01 and 4.01 buffer solution, stored in $\mathrm{KCl}$ solution, HANNA instruments, USA). After the study, above-ground biomass was harvested from all plots (Barcianicha, 29 October 2012; Giel'cykaŭ Kašyl', 11 September 2012), oven dried at $60^{\circ} \mathrm{C}$ till weight constancy, and three mixed samples per plot were analysed for total $\mathrm{C}$ and $\mathrm{N}$.

Vegetation cover of the $70 \mathrm{~cm} \times 70 \mathrm{~cm}$ plots was assessed in coverage classes after Peet et al. (1998). Nomenclature for vascular plants and mosses follows Rothmaler (2002), and Abramov and Volkova (1998), respectively. The nutrient status of the sites was estimated by plant species groups as indicator (Koska et al., 2001).

Water levels were measured continuously (daily averages stored) with Mini-Diver data loggers (Eigenbrodt, Germany), installed in perforated tubes (inner diameter $46 \mathrm{~mm}$ ). One Mini-Diver was situated next to BA Carex-Equisetum in Barcianicha, and another in the middle between the floating tall sedge - Typha latifolia sites and GK PhragmitesLemna in Giel'cykaŭ Kašyl'. Manual water level measurements were conducted at each site in every second to third week. Daily water levels relative to ground surface were calculated for every plot by linear regression between the 
continuous automatic water level time series and manually measured water levels. Because of strong peat oscillation this approach did not work for the floating sites GK TyphaHydrocharis and GK Carex-Lysimachia. Photographic documentation (monthly during vegetation season, one time per winter, WL estimation error $<5 \mathrm{~cm}$ ) was used here instead to reconstruct relative water levels for linear regression with Mini-Diver records.

\subsection{Measurement of greenhouse gas exchange}

In order to account for typical small-scale differences between vegetation types we applied a manual chamber approach to measure greenhouse gas exchange. Each of the six GHG measurement sites was equipped with three plastic collars of $70 \mathrm{~cm} \times 70 \mathrm{~cm}$, established in a row about $40 \mathrm{~cm}$ apart from each other. Each collar represents one plot. The row was east-west oriented and the north side was the working side to minimize artificial shading during measurements. Collars were inserted $15 \mathrm{~cm}$ deep into the peat at Barcianicha. At Giel'cykaŭ Kašyl' because of the high water level, collars were fixed on tubes orthogonally inserted into the peat and anchored in the underlying sand. Measurements were conducted from pre-installed boardwalks from August 2010 to August 2012.

$\mathrm{CO}_{2}$ exchange was measured with transparent chambers made of plexiglas ( $88 \%$ light transmission, ice packs for cooling, Drösler, 2005) and opaque chambers made of grey ABS plastic covered with a white film. Both were equipped with fans for air mixing and had an inner size $72.5 \mathrm{~cm} \times 72.5 \mathrm{~cm} \times 51.2 \mathrm{~cm}$. Opaque and transparent extensions of same area and 31.2 or $51.2 \mathrm{~cm}$ height with open tops were used to enlarge the chambers to accommodate for tall plants. Chambers and extensions were sealed airtight by closed cell rubber tubes attached to the bottom rims (Drösler, 2005). Carbon dioxide concentrations were measured continuously by circulating air in a closed loop between the chamber and an infrared gas analyser (LI-820, LICOR Biosciences, USA) and recorded every $5 \mathrm{~s}$ by a data logger (CR200 or CR1000, Campbell Scientific, USA). Simultaneously, air temperature inside and outside the chamber, and PAR were recorded automatically ("109" temperature probes protected by radiation sheets, SKP215, Campbell Scientific, USA), while soil temperatures were measured manually in 2,5 , and $10 \mathrm{~cm}$ depth once per chamber measurement with Pro-DigiTemp insertion thermometers (Carl Roth, Germany). For $\mathrm{CO}_{2}$ measurements bright or hardly cloudy days were selected to capture the complete PAR range from zero to solar noon. During the 1-day measurement campaigns 8 to 10 transparent chamber measurements of 2-3 min were carried out on each plot from dawn until late afternoon. Measurements were equally distributed over the daily range of PAR to determine light response of gross primary production (GPP). A similar number of opaque chamber measurements of 3-5 min were performed over the same period to capture the temperature response of ecosystem respiration $\left(R_{\text {eco }}\right)$. Measurement campaigns were repeated every third to fourth week to account for seasonal changes in water table depth and plant development.

$\mathrm{CH}_{4}$ and $\mathrm{N}_{2} \mathrm{O}$ fluxes were measured once every second to third week during the snow-free period and monthly during winter using non-air mixed opaque chambers, of the same material as the other opaque chambers, but shaped as a truncated pyramid (inner size at bottom $72.5 \mathrm{~cm} \times 72.5 \mathrm{~cm}$, inner size at top $62.5 \mathrm{~cm} \times 62.5 \mathrm{~cm}$, height $51.2 \mathrm{~cm}$ ). Four to five air samples were taken from the chamber headspace during a 15-20 min enclosure and subsequently analysed in the laboratory with a gas chromatograph (Chromatec-Cristal 5000.2, Chromatec, Russia), using an electron capture detector (ECD) for analysing $\mathrm{N}_{2} \mathrm{O}$ and a flame ionization detector (FID) for $\mathrm{CH}_{4}$, and an auto-sampler (Loftfield, Germany). From August 2010 to August 2012 a total of $36 \mathrm{CH}_{4}$ and $\mathrm{N}_{2} \mathrm{O}$ as well as $26 \mathrm{CO}_{2}$-measuring campaigns were carried out at every site.

Diurnal $\mathrm{CH}_{4}$ emission dynamics and the effect of chamber transparency and headspace mixing were additionally studied at one plot per site by frequent $\mathrm{CH}_{4}$ measurements for one to two summer days, using alternately two (opaque and transparent, both with fan) or three (opaque and transparent with and opaque without fan) chamber types (for details cf. Minke et al., 2014).

Parameters for the development of flux models were recorded on site during GHG-measurement campaigns, and monitored continuously by nearby climate stations (BA: Višnieva, $5.6 \mathrm{~km}$ NW of Barcianicha, and GK: Z'dzitava, $6.3 \mathrm{~km}$ NE of Giel'cykaŭ Kašyl'). At the stations soil temperatures in 2 and $5 \mathrm{~cm}$ depth, and air temperature $20 \mathrm{~cm}$ above surface were measured with "109" temperature probes (Campbell Scientific, USA). Photosynthetically active radiation (PAR) was monitored using a SKP215 Quantum Sensor, precipitation with the R.M. Young 52202 Tipping Bucket Rain Gauge (heated), atmospheric pressure with CS100 Setra Barometric Sensor, and all data were recorded halfhourly with CR200 data loggers (all devices from Campbell Scientific, USA). Regression between site and climate station temperature data was subsequently applied to derive continuous half-hourly time series for each site. Due to technical problems with the rain gauges precipitation data were received from Gidrometcentr, Belarus, from the weather stations in Valožyn $(15 \mathrm{~km}$ E of Barcianicha) and Pružany ( 54 km WNW of Giel'cykaŭ Kašyl'). Data from both weather stations of Gidrometcentr were also used to calculate 30 years (1979-2008) monthly averages of air temperature and precipitation. 


\subsection{Calculation of flux rates, annual emission models, and uncertainties}

\subsubsection{Carbon dioxide}

The net ecosystem exchange (NEE, the $\mathrm{CO}_{2}$ flux between the ecosystem and the atmosphere) is the balance between $\mathrm{CO}_{2}$ inputs to the ecosystem by gross primary production (GPP) and $\mathrm{CO}_{2}$ losses by ecosystem respiration $\left(R_{\mathrm{eco}} ; \mathrm{Alm}\right.$ et al., 1997; Chapin III et al., 2002). A positive sign refers to a flux from the ecosystem to the atmosphere, a negative sign to an ecosystem sink (cf. Falge et al., 2001). Annual NEE rates were modelled for each plot separately based on the plot and campaign specific relationships between $R_{\text {eco }}$ and temperature, as well as between GPP and PAR.

Modelling NEE using the approach of Hoffmann et al. (2015) resulted in surprisingly high annual net $\mathrm{CO}_{2}$ uptake rates of the Phragmites australis sites. To check for possible impacts of the calculation routine on the result we used alternatively the approach of Leiber-Sauheitl et al. (2014) and arrived at slightly smaller $\mathrm{CO}_{2}$ sinks. Both approaches are reasonable, build on the same assumptions but differ with respect to flux estimation, reference temperature, GPP model and importance of the significance of the model fits, as described in the following paragraphs. To avoid that modelled $\mathrm{CO}_{2}$ exchange rates would be biased by specific features of only one of the approaches, both approaches were used to model annual $\mathrm{CO}_{2}$ exchange rates and their means were taken as final estimates. However, for simplicity we only present modelled $\mathrm{CO}_{2}$ time series derived by the Hoffmann (H) approach.

\section{Calculation of measured $\mathrm{CO}_{2}$ flux rates}

Measured $\mathrm{CO}_{2}$ flux rates were calculated in both approaches as linear $\mathrm{CO}_{2}$ concentration change in the chamber over time. Measurements were discarded if PAR fluctuated by $> \pm 10 \%$ (transparent chambers) and chamber temperature $> \pm 0.75 \mathrm{~K}$ (transparent and opaque chambers) from the mean of the selected flux calculation interval. In the $\mathrm{H}$ approach a moving window of variable time was applied to adjust the starting point and length of the regression sequence according to the regression quality. The optimal flux length was selected in a second step, based on the minimum Akaike information criterion (AIC) of the flux fit to the $R_{\text {eco }}$ or the GPP functions. In the Leiber-Sauheitl (LS) approach a moving window of constant length ( $1 \mathrm{~min}$ for all except for $2 \mathrm{~min}$ for opaque flux measurements at Phragmites australis plots because of large chamber volumes and slow concentration changes) was used to select the regression sequence with maximum $R^{2}$ and minimum variance. If maximum $R^{2}$ resulted in different fluxes than minimum variance ( $46 \%$ of all flux measurements) the mean of both was used as flux estimate.

\section{Modelling of half-hourly $\mathrm{CO}_{2}$ exchange rates}

In both approaches the Lloyd and Taylor (1994) equation (Eq. 1) was fitted to $R_{\text {eco }}$ flux data against site temperatures for each plot and campaign.

$R_{\text {eco }}=R_{\text {ref }} \times \exp \left[E_{0} \times\left(\frac{1}{T_{\text {ref }}-T_{0}}-\frac{1}{T-T_{0}}\right)\right]$

$R_{\text {eco }}=$ ecosystem respiration $\left(\mathrm{mg} \mathrm{CO}_{2}-\mathrm{C} \mathrm{m}^{-2} \mathrm{~h}^{-1}\right), R_{\text {ref }}=$ $R_{\text {eco }}$ at reference temperature $\left(\mathrm{mg} \mathrm{CO}_{2}-\mathrm{C} \mathrm{m}^{-2} \mathrm{~h}^{-1}\right)$, $E_{0}=$ activation energy like parameter $(\mathrm{K}), T_{\text {ref }}=$ reference temperature $(283.15 \mathrm{~K}), T_{0}=$ temperature constant for the start of biological processes: $(227.13 \mathrm{~K}), T=$ soil or air temperature during measurement of best fit with the dataset $(\mathrm{K})$.

In the $\mathrm{H}$ approach Eq. (1) was fitted to $R_{\text {eco }}$ flux rates separately for air temperature and soil temperatures and the final $R_{\text {eco }}$ parameter pairs were selected out of all significant $(p \leq 0.1)$ sets based on the lowest AIC. If parameterization was not significant or failed, or if the daily temperature amplitude was below $3 \mathrm{~K}$, the average $\mathrm{CO}_{2}$ flux of the measurement campaign was used. In the LS approach, one $R_{\text {eco }}$ fit per plot and campaign was calculated against air temperatures. If parameterization was impossible or the temperature amplitude was below $2 \mathrm{~K}$, the mean campaign $R_{\text {eco }}$ flux was used.

In a second step GPP fluxes were determined by subtracting modelled $R_{\text {eco }}$ fluxes from temporally corresponding measured NEE flux rates. In the $\mathrm{H}$ approach a rectangular hyperbola equation (Michaelis and Menten, 1913; Eq. 2) was fitted to the relation between PAR and GPP flux rates to calibrate GPP parameter sets of $\alpha$ (initial slope of the curve; light use efficiency) and $\mathrm{GP}_{\max }$ (rate of carbon fixation for infinite PAR).

$\mathrm{GPP}=\frac{\alpha \times \mathrm{PAR} \times \mathrm{GP}_{\max }}{\alpha \times \mathrm{PAR}+\mathrm{GP}_{\max }}$

GPP parameter pairs with lowest AIC were selected from each campaign out of all significant regression parameters $(p \leq 0.1)$. If the parameter estimation failed, a non rectangular hyperbolic equation was fitted to the data (Gilmanov et al., 2007). If this failed, too, an average parameter approach was used. Assuming declining GPP fluxes when PAR drops from 500 to $0 \mu \mathrm{mol} \mathrm{m}{ }^{-2} \mathrm{~s}^{-1} \alpha$ was set -0.01 and $\mathrm{GP}_{\max }$ estimated as the mean campaign GPP flux. In the LS approach the modified Michaelis-Menten model of Falge et al. (2001; Eq. 3) was applied and GP2000 was calculated instead of $\mathrm{GP}_{\max }$, i.e. the rate of carbon fixation at PAR of $2000 \mu \mathrm{mol} \mathrm{m}^{-2} \mathrm{~s}^{-1}$. Campaigns for which no GPP fit was found were skipped.

$\mathrm{GPP}=\frac{\alpha \times \mathrm{PAR} \times \mathrm{GP} 2000}{\mathrm{GP} 2000+\alpha \times \mathrm{PAR}-\frac{\mathrm{GP} 2000}{2000} \times \mathrm{PAR}}$

Based on the GPP parameter pairs and continuously monitored PAR data, GPP was modelled in both approaches for 
each plot at a temporal resolution of $30 \mathrm{~min}$. NEE was subsequently calculated as the difference between GPP and $R_{\text {eco }}$.

\section{Uncertainty, accuracy, and variability}

Model performance for the interpolation between the measurement campaigns was estimated for the $\mathrm{H}$ approach by leave-one-out cross-validation. Stepwise one measurement campaign was left out after the other and the modelled $R_{\text {eco }}$ and NEE fluxes were compared with the measured fluxes in the left out campaigns. Model performance was assessed by the Nash-Sutcliffe efficiency (NSE, Moriasi et al., 2007).

The random error of the annual $\mathrm{CO}_{2}$ balances was calculated for the $\mathrm{H}$ approach using the R-script Version 1.1 of Hoffmann et al. (2015). Campaign specific confidence intervals $(p=0.01)$ were determined for the temperature models, as well as for the $R_{\text {eco }}$ and GPP parameter pairs by bootstrapping. Subsequently 100 samples were taken randomly from the confidence intervals and used to compute $R_{\text {eco }}$, GPP, and NEE models. The random error of the $\mathrm{CO}_{2}$ models calculated with the $\mathrm{H}$ approach represents the model uncertainty at the days of the measurement campaigns, but not of the interpolation. As indicated by the differences between the $\mathrm{H}$ and LS approaches, the uncertainty of the annual balances is larger. To arrive at more realistic error estimates we accounted for the random error and for the difference between both approaches and defined the confidence intervals as the difference between the annual sums of both approaches plus 2 times the annual random error calculated for the $\mathrm{H}$ approach.

\subsubsection{Methane and nitrous oxide}

\section{Calculation of fluxes}

Methane fluxes were estimated with the $\mathrm{R}$ package "flux 0.2-1" (Jurasinski et al., 2012) using linear regression. For normalized root mean square error (NRMSE) $<0.2$ the flux with the largest number of concentration measurements was preferred. If NRMSE $\geq 0.2$ a set of fluxes was estimated using the maximum number up to at least three concentration measurements. Subsequently the flux with the lowest NRMSE was selected. Fluxes were accepted if NRMSE $<0.4, R^{2} \geq 0.8$ and $n \geq 3$. This was the case in 639 out of 686 methane flux measurements, with 477 accepted fluxes based on $n \geq 4$.

Nitrous oxide flux rates and their standard deviations were calculated with linear regression using the same air samples as accepted for $\mathrm{CH}_{4}$ flux calculation.

\section{Modelling of emissions}

Methane fluxes correlated with some environmental factors. This allowed to develop a univariate nonlinear regression model for daily methane fluxes. The relatively small number of observations did not allow any multivariate approaches.
First, the relation between environmental factors (air temperature, soil temperature, water level, air pressure, PAR, GPP, $R_{\text {eco }}, \mathrm{NEE}$ ) and measured $\mathrm{CH}_{4}$ fluxes was tested for each plot using non-parametric Spearman's correlation to identify the strongest driving parameter. Second, several published nonlinear regression models (Eqs. 1, 4, 5) were fitted to the relation between methane emissions and the driver and the optimal model was selected based on the AIC.

The strongest Spearman's $\rho$ correlations were found between methane fluxes and instantaneous on site soil temperature (median $\rho$ for 2 years and all 18 plots $=0.85, n=36$ ), followed by half-hourly and daily $R_{\text {eco }}$ (both 0.83 ), halfhourly GPP ( -0.80 ; both modelled with the $\mathrm{H}$ approach), and on site air temperature (0.75). Mean daily site specific soil temperatures, calculated by linear regression between site measurements and climate station data, also correlated well with methane fluxes (median $\rho$ per plot and year $=0.85$ ) and had a strong covariance with other factors. Water level did not correlate significantly with methane emissions at any plot, possibly because it was always close to or above the surface. Therefore mean daily soil temperature was chosen as the single driving factor for modelling methane emission.

The temperature dependency of methane production and emission was previously described by the Arrhenius function or its logarithmic form (Conrad et al., 1987; Schütz et al., 1990; Daulat and Clymo, 1998; Kim et al., 1998):

$F=A \times e^{\frac{-E}{R \times T}}$,

where $F=$ flux rate of $\mathrm{CH}_{4} \quad\left(\mathrm{mgCH}_{4}-\mathrm{C} \mathrm{m}^{-2} \mathrm{~h}^{-1}\right)$, $A=$ Arrhenius $\quad$ parameter $\quad\left(\mathrm{mgCH}_{4}-\mathrm{C} \mathrm{m}^{-2} \mathrm{~h}^{-1}\right)$, $E=$ apparent activation energy $\left(\mathrm{J} \mathrm{mol}^{-1}\right), R=$ gas constant (8.314 $\mathrm{J} \mathrm{mol}^{-1} \mathrm{~K}^{-1}$ ), and $T=$ soil temperature $(\mathrm{K})$.

Also an exponential function or its logarithmic form has been widely applied to calculate methane emission in relation to temperature (Dise et al., 1993; Saarnio et al., 1997; Kettunen et al., 2000; Tuittila et al., 2000; Laine et al., 2007; Rinne et al., 2007; Wilson et al., 2009):

$F=a \times e^{b \times T}$,

where $F=$ flux rate of $\mathrm{CH}_{4}\left(\mathrm{mg} \mathrm{CH}_{4}-\mathrm{C} \mathrm{m}^{-2} \mathrm{~h}^{-1}\right), a=$ flux rate at $T=0{ }^{\circ} \mathrm{C}\left(\mathrm{mg} \mathrm{CH}_{4}-\mathrm{C} \mathrm{m}^{-2} \mathrm{~h}^{-1}\right), \quad b=$ coefficient $\left({ }^{\circ} \mathrm{C}^{-1}\right)$, and $T=$ soil temperature $\left({ }^{\circ} \mathrm{C}\right)$. The third tested function was the Lloyd and Taylor (1994) equation for soil respiration (Eq. 1, Sect. 2.4.1). We used the AIC to select from Eqs. (1), (4), and (5) the one that best fitted to our data set. The differences were small but the AIC of the Lloyd and Taylor equation (Eq. 1) was the smallest for 33 out of 36 fits (fits for 2 years and 18 plots) and was therefore chosen to model methane emissions for all plots and years.

As $\mathrm{N}_{2} \mathrm{O}$ fluxes did not correlate with recorded environmental factors annual emissions were estimated by linear interpolation between measurements. 


\section{Uncertainty, accuracy, and variability}

Model performance was tested by leave-one-out crossvalidation. Errors of modelled annual methane emissions were calculated using Monte Carlo simulation in four steps. We included the uncertainty of the temperature transfer from the climate station to the site, the uncertainty of the measured flux rates, and the parameter uncertainty of the Lloyd and Taylor fits. Temperature uncertainty was quantified by 1000 times repeated bootstrapped re-sampling of site and station temperatures with the same indices. Second, a set of 1000 normally distributed flux values was generated for every flux measurement based on the calculated $\mathrm{CH}_{4}$ flux rates and their standard deviation. Third, each of the 1000 soil temperature data set was paired with one of the 1000 flux data sets and 1000 Lloyd and Taylor fits (Eq. 1) were performed. Fourth, from each of the Lloyd and Taylor fits 1000 bootstrap parameter samples were created using bootstrap of the residuals (Efron, 1979; Leiber-Sauheitl et al., 2014). More than $99 \%$ of the bootstrap fits were successful what resulted in more than 990000 parameter pairs per plot and year. Finally, 1000 Lloyd and Taylor fits were randomly sampled from the parameter pairs, combined with the 1000 soil temperature data set and used to calculate 1000 methane models per plot and year. For each time point and the annual sums 95 and $5 \%$ quantiles were calculated to construct confidence intervals of the time series and annual gas balances. As the $\mathrm{CH}_{4}$ model fits include the temperature and methane flux uncertainties over the entire year, the $90 \%$ confidence intervals do to some extent also account for the interpolation between measurement days.

Uncertainties of annual $\mathrm{N}_{2} \mathrm{O}$ fluxes were calculated solely based on estimates and standard deviations of the measured fluxes. 1000 normally distributed values of each flux were generated and linearly interpolated. This resulted in 1000 annual emission estimates per plot and year, but the calculated $90 \%$ confidence intervals represent only the uncertainties of the measured fluxes.

\subsection{Statistical analyses}

Correlations between annual balances of $\mathrm{CH}_{4}$ and $\mathrm{CO}_{2}$ with site factors were tested using the non-parametric Spearman's $\rho$.

Differences of daytime methane fluxes among chamber types were analysed using either the Mann-Whitney test or the Kruskal-Wallis test with the post-hoc nonparametric Tukey-type multiple comparison procedure developed by Nemenyi (Zar, 1999).

\section{Results}

\subsection{Site conditions}

Most of the residual peat at both peatlands was very slightly to moderately decomposed radicel peat (Table 1). Surface peat was eutrophic and acid at both study sites, but less decomposed at Barcianicha as compared to Giel'cykaŭ Kašyl' (Table 1). Barcianicha had 27 to $76 \mathrm{~cm}$ thick layers of brown moss peat about $40 \mathrm{~cm}$ below surface, while for Giel'cykaŭ Kašyl' notable amounts of Phragmites macrofossils were found in the upper 100 to $140 \mathrm{~cm}$ of the profile.

Vegetation was homogeneous within sites types at Barcianicha and varied little between years (Table A1). Vegetation indicated mesotrophic conditions at Barcianicha (Koska et al., 2001). At Giel'cykaŭ Kašyl' species cover was homogeneous among plots and years for GK PhragmitesLemna (Table A1). The floating sites GK Carex-Lysimachia and GK Typha-Hydrocharis constituted a strongly interweaved fine mosaic of sedge tussocks and cattail and shared many species. Vegetation indicated eutrophic conditions for Giel'cykaŭ Kašyl' (Koska et al., 2001).

Mean annual temperature at Barcianicha was $6.5^{\circ} \mathrm{C}$ in the first and $6.9^{\circ} \mathrm{C}$ in the second measurement year, close to the long term mean $\left(6.4^{\circ} \mathrm{C}, 1979-2008\right)$. Annual precipitation in the first year $(740 \mathrm{~mm})$ was higher than the long-term mean $(665 \mathrm{~mm})$ due to heavy summer rains (Fig. 2a), but lower $(633 \mathrm{~mm})$ in the second.

Giel'cykaŭ Kašyl' (Fig. 2b) was generally warmer and drier than Barcianicha (long-term mean $7.3^{\circ} \mathrm{C}$ and $594 \mathrm{~mm}$, respectively, 1979-2008). Also here the first year was wetter $(804 \mathrm{~mm})$ and the second year drier $(500 \mathrm{~mm})$ and annual temperatures were close to the long term mean $\left(7.3^{\circ} \mathrm{C}\right.$ in the first year; $7.9^{\circ} \mathrm{C}$ in the second year).

Annual water levels relative to the surface at Barcianicha decreased in the order BA Phragmites-Carex $(14 \pm 2 \mathrm{~cm}$ above surface), BA Carex-Equisetum and BA EriophorumCarex (at surface; Table 1). Differences among plots within sites were small (Fig. 4c, d, and e). Annual values for both years were the same (Table 1). Summer and winter median water levels were very similar, despite temporal fluctuations of up to $18 \mathrm{~cm}$.

Water tables at GK Phragmites-Lemna (Giel'cyka Kašyl') were about $1 \mathrm{~m}$ in the first year, and dropped to about $70 \mathrm{~cm}$ above surface in the second year (Table 1). At the close by floating tall sedge - Typha latifolia reed sites water levels were only about $10 \mathrm{~cm}$ above the surface and the drop from the first to the second year was small, both because of the oscillating peat surface. Summer water levels were lower than winter levels, but never dropped significantly below surface (Table 1, Fig. 4n and o). Annual water levels varied more among plots than at Barcianicha, with a maximum of $11 \mathrm{~cm}$ at GK Phragmites-Lemna (Fig. 4p).

Above-ground biomass harvested in autumn 2012 at Barcianicha (Table 1) was largest for BA Phragmites- 


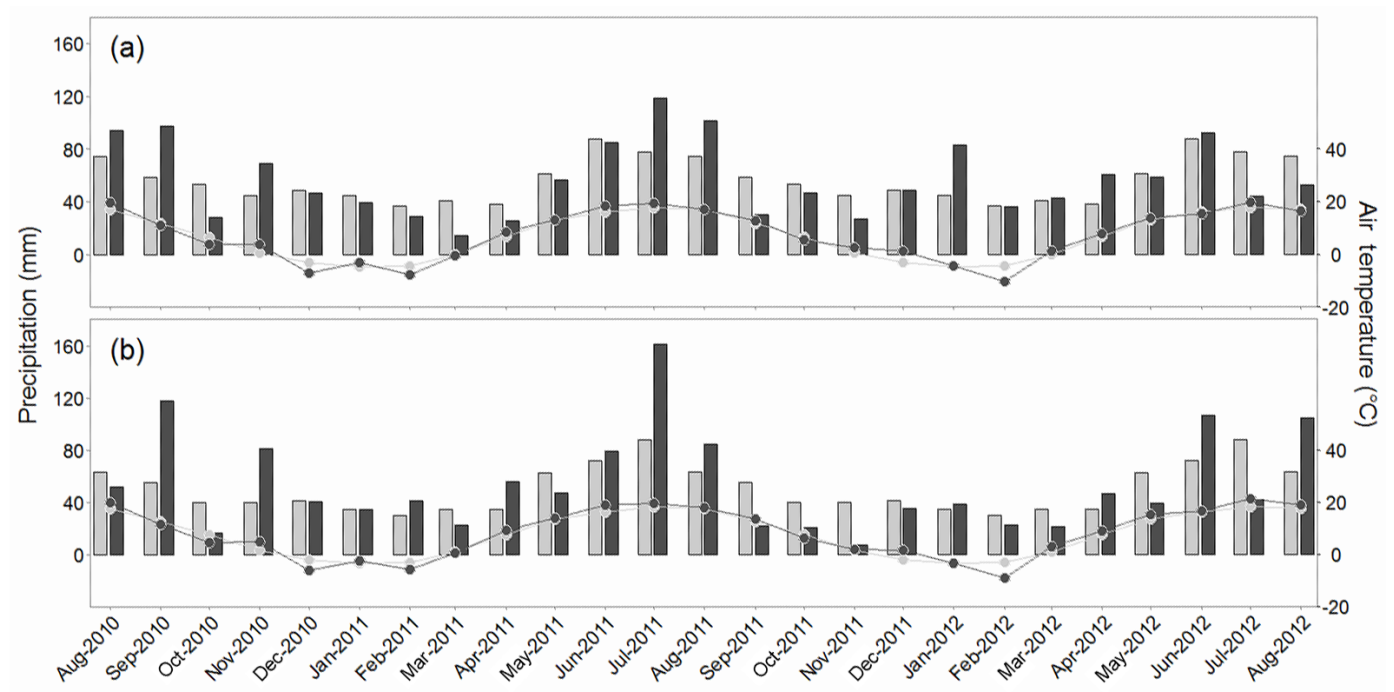

Figure 2. Cumulative monthly precipitation (bars) and average monthly air temperatures (dots) for Barcianicha (a) and Giel'čykaŭ Kašyl' (b). Actual temperatures (black) were measured in (a) Višnieva, $5.6 \mathrm{~km} \mathrm{NW}$ of Barcianicha, and (b) Z'dzitava, 6.3 km NE of Giel'čykaŭ Kašyl'. Actual precipitation data (black) and 30 year averages (1979-2008) of temperatures and precipitation (grey) are from meteorological stations of "Gidrometcentr" in (a) Valožyn, 15 km E of Barcianicha, and (b) Pružany, 54 km WNW of Giel'čykaŭ Kašyl'.
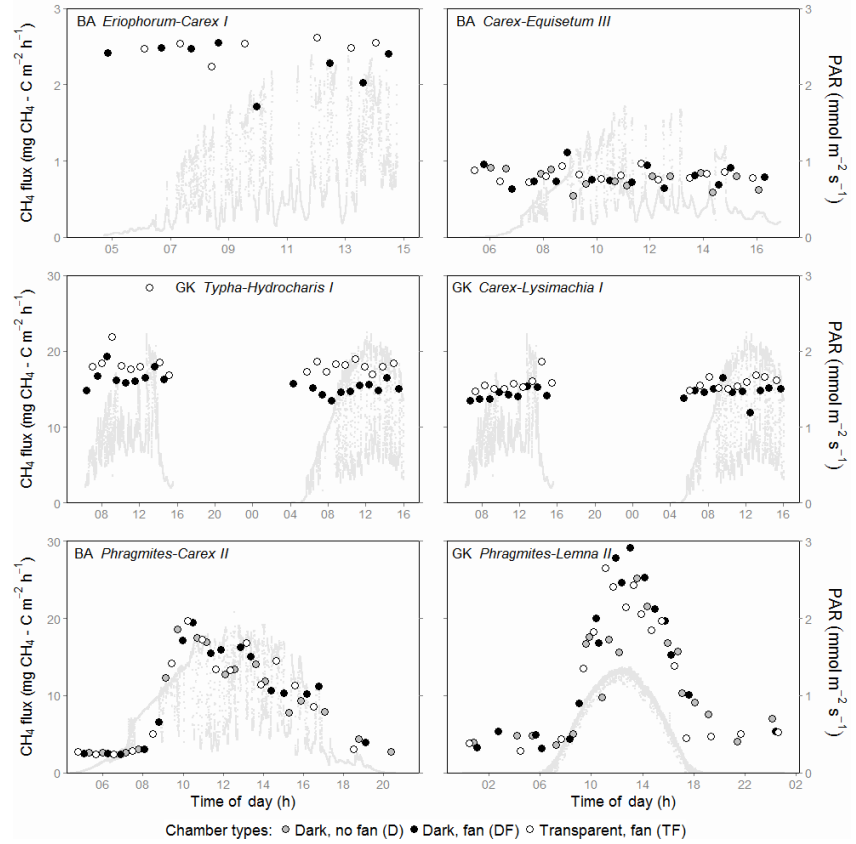

Figure 3. Diurnal variation of methane emissions, measured with different chamber types, and outside PAR, at BA EriophorumCarex (plot I, 18 July 2012), BA Carex-Equisetum (plot III, 16 September 2012), BA Phragmites-Carex (plot II, 8 August 2012), GK Typha-Hydrocharis and GK Carex-Lysimachia (both plot I, 12 July 2012 and 13 July 2012), and GK PhragmitesLemna (plot II, 21 September 2011). Data of BA Phragmites-Carex and GK Phragmites-Lemna are from Minke et al. (2014).
Carex $\left(296 \pm 79 \mathrm{~g} \mathrm{C} \mathrm{m}^{-2}\right)$, lower for BA EriophorumCarex $\left(117 \pm 34 \mathrm{~g} \mathrm{C} \mathrm{m}^{-2}\right)$, and smallest for BA CarexEquisetum $\left(55 \pm 22 \mathrm{~g} \mathrm{C} \mathrm{m}^{-2}\right)$. Biomass harvests of $\mathrm{GK}$ Typha-Hydrocharis and GK Carex-Lysimachia were similar to BA Phragmites-Carex, but that of GK PhragmitesLemna were 2 times larger $\left(586 \pm 121 \mathrm{~g} \mathrm{C} \mathrm{m}^{-2}\right.$, Table 1). The doubled biomass production of Phragmites australis at Giel'cykaŭ Kašyl' compared to Barcianicha supports the nutrient rich conditions, probably resulting from different water supply (river and grassland drainage water for GK, groundwater for BA) and different land use history (after peat extraction temporary grassland before rewetting of GK, rewetting directly after peat extraction of BA).

\subsection{Carbon dioxide emissions}

Model performance tested for the $\mathrm{H}$ approach was good for both years and all site types and plots. Cross-validation resulted in a median NSE of 0.78 (range from 0.38 to 0.90 ) for the $R_{\text {eco }}$ models and of 0.76 ( 0.21 to 0.91$)$ for the NEE models.

All sites of Barcianicha were net $\mathrm{CO}_{2}$ sinks in the first year. NEE was -528 (90\% confidence interval -933 , -194) $\mathrm{g} \mathrm{CO}_{2}-\mathrm{C} \mathrm{m}^{-2} \mathrm{yr}^{-1}$ for BA Phragmites-Carex, -86 $(-130,-38) \mathrm{g} \mathrm{CO}_{2}-\mathrm{C} \mathrm{m}^{-2} \mathrm{yr}^{-1}$ for BA Eriophorum-Carex and $-88(-114,-68) \mathrm{g} \mathrm{CO}_{2}-\mathrm{C} \mathrm{m}^{-2} \mathrm{yr}^{-1}$ for CarexEquisetum (Fig. 5, Table 2). In the second year, resulting from increased $R_{\text {eco }}$ and decreased GPP, the net $\mathrm{CO}_{2}$ uptake decreased. NEE of BA Phragmites-Carex dropped to -329 $(-431,-220) \mathrm{g} \mathrm{CO}_{2}-\mathrm{C} \mathrm{m}^{-2} \mathrm{yr}^{-1}$, BA Eriophorum-Carex became $\mathrm{CO}_{2}$ neutral and BA Carex-Equisetum turned into a small source of $24(-6,55) \mathrm{g} \mathrm{CO}_{2}-\mathrm{C} \mathrm{m}^{-2} \mathrm{yr}^{-1}$. 

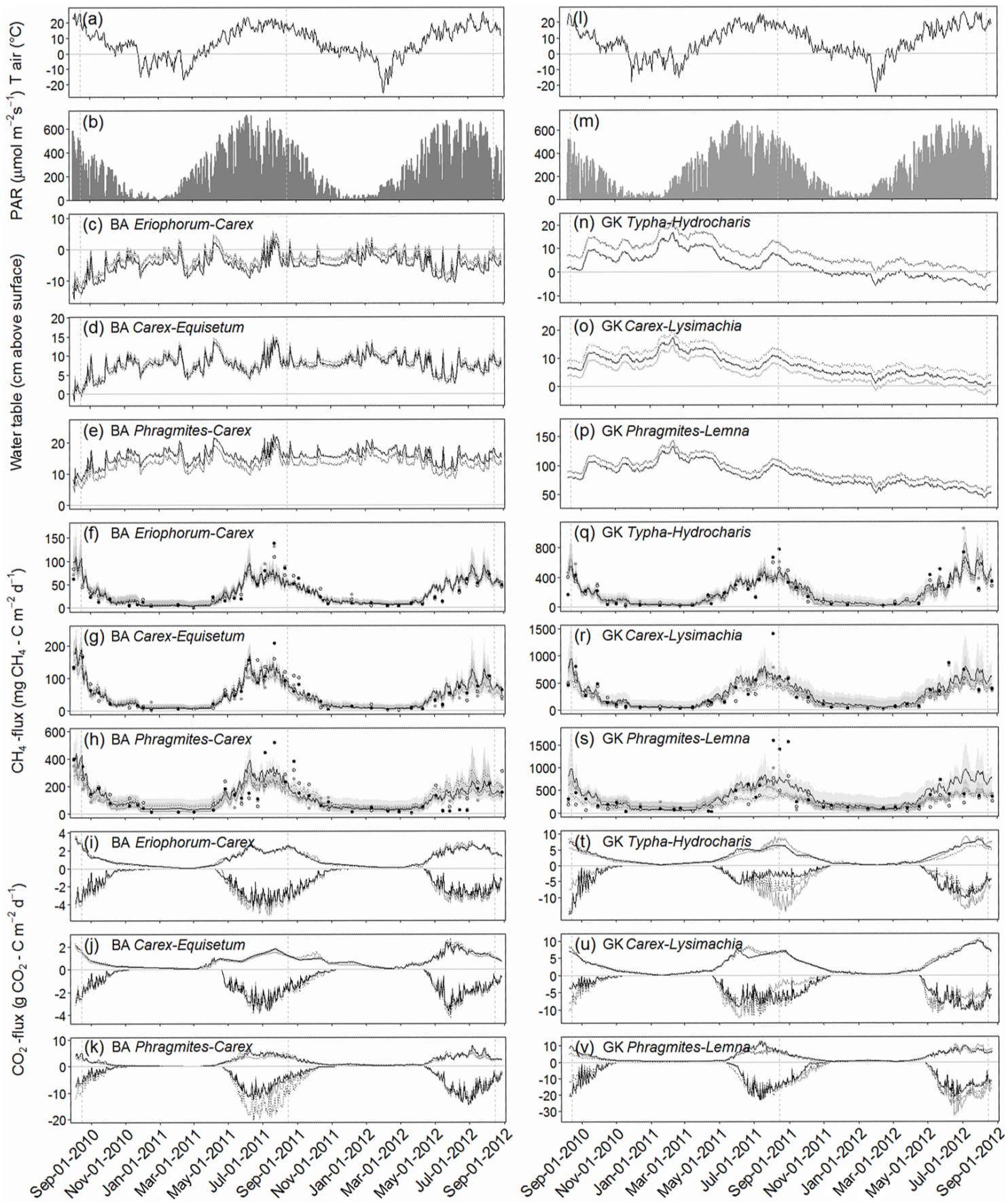

Plots in (c) to (k) and in (n) to $(v):-1 \cdot\|\cdot 1\|$

Figure 4. Mean daily air temperature (a) and mean daily PAR (b) at Višnieva (a, b) and Z'dzitava (l, m), mean daily water table positions, mean daily measured (points) and modelled (lines) $\mathrm{CH}_{4}$ fluxes, and mean daily modelled (H approach) GPP, and $R_{\mathrm{eco}}(\mathbf{i}, \mathbf{j}$, $\mathbf{k})$ of Barcianicha (c-k) and Giel'čykaŭ Kašyl' sites (n-v).

Both, sinks and sources were larger at the Giel'cykaŭ Kašyl' sites. NEE of GK Phragmites-Lemna was -611 $(-819,-450) \mathrm{g} \mathrm{CO}_{2}-\mathrm{C} \mathrm{m}^{-2} \mathrm{yr}^{-1}$ in the first and, despite of increasing $R_{\text {eco }}$ fluxes, $-1175(-1567,-690)$ $\mathrm{g} \mathrm{CO}_{2}-\mathrm{C} \mathrm{m}^{-2} \mathrm{yr}^{-1}$ in the second year. The high values were attributed to extremely high annual GPP reaching -2267 $(-2733,-1843) \mathrm{g} \mathrm{CO}_{2}-\mathrm{C} \mathrm{m}^{-2} \mathrm{yr}^{-1}$ in the second year, equivalent to twice the $R_{\text {eco }}$ fluxes (Fig. 5, Table 3). At the other Giel'cykaŭ Kašyl' sites $R_{\text {eco }}$ and GPP also increased from the first to the second year, but $R_{\mathrm{eco}}$ and 


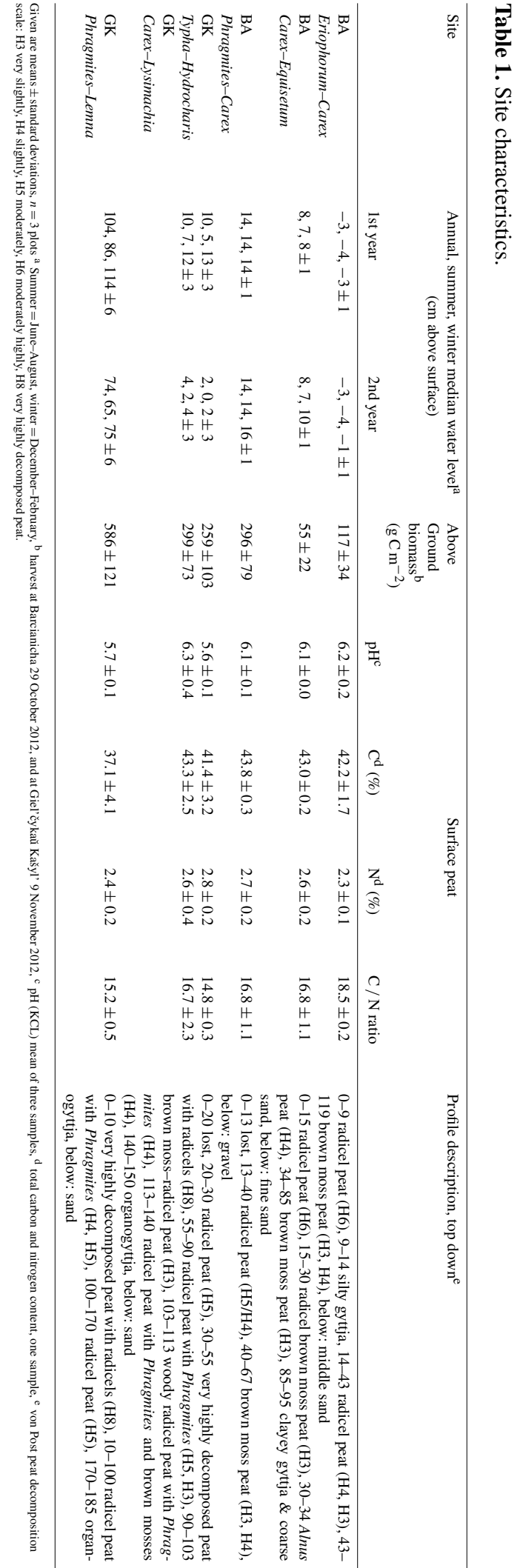

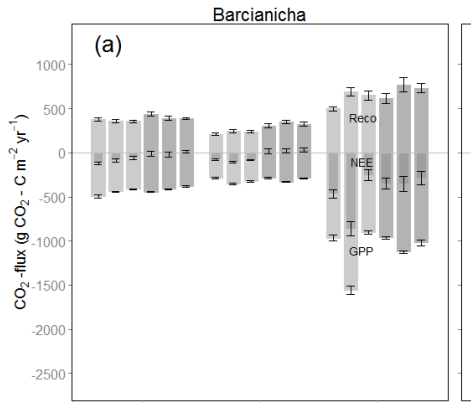
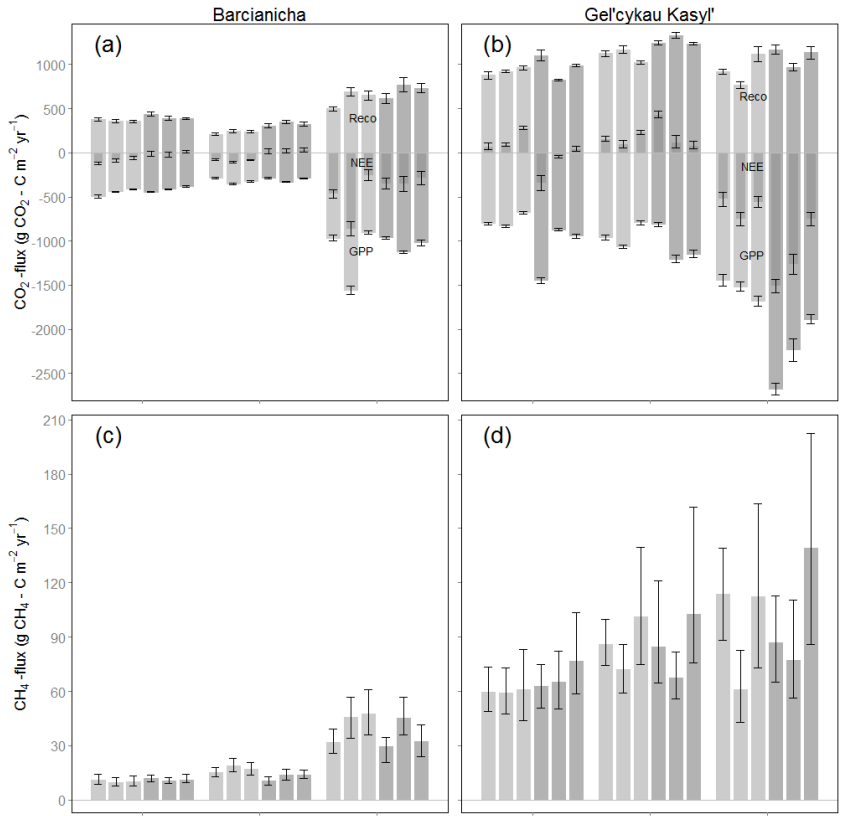

(d)

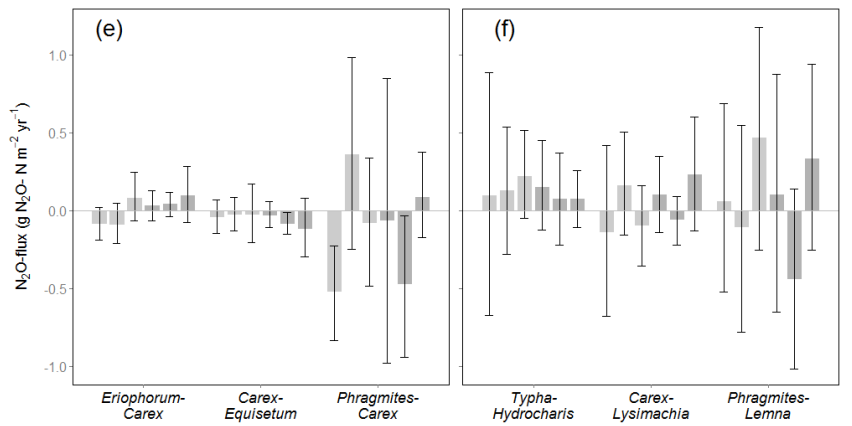

Figure 5. Annual $\mathrm{CO}_{2}$ (NEE, $R_{\mathrm{eco}}$, GPP), $\mathrm{CH}_{4}$ and $\mathrm{N}_{2} \mathrm{O}$ fluxes at Barcianicha (a, c, e) and Giel'čykaŭ Kašyl' (b, d, f). Uncertainties for $\mathrm{CO}_{2}$ fluxes are $50 \%$ of the difference between both modelling approaches plus the $90 \%$ confidence intervals of the $\mathrm{H}$ approach. Uncertainties for $\mathrm{CH}_{4}$ represent $90 \%$ confidence intervals of the models, but for $\mathrm{N}_{2} \mathrm{O}$ only $90 \% \mathrm{CI}$ of the measured $\mathrm{N}_{2} \mathrm{O}$ fluxes. Light grey $=1$ st year, darker grey $=2$ nd year. Plots are ordered $\mathrm{I}$, II, III.

GPP largely balanced each other. GK Typha-Hydrocharis consequently varied between a source of $151(41,300)$ $\mathrm{g} \mathrm{CO}_{2}-\mathrm{C} \mathrm{m}^{-2} \mathrm{yr}^{-1}$ in the first and a sink of $-113(-418$, 66) $\mathrm{g} \mathrm{CO}_{2}-\mathrm{C} \mathrm{m}^{-2} \mathrm{yr}^{-1}$ in the second year. GK CarexLysimachia was a net $\mathrm{CO}_{2}$ source in both years, releasing $166(66,252) \mathrm{g} \mathrm{CO}_{2}-\mathrm{C} \mathrm{m}^{-2} \mathrm{yr}^{-1}$ in the first and $216(48$, 470) $\mathrm{g} \mathrm{CO}_{2}-\mathrm{C} \mathrm{m}^{-2} \mathrm{yr}^{-1}$ in the second year.

On average the net $\mathrm{CO}_{2}$ sink at Barcianicha decreased in the second year by $130 \mathrm{~g} \mathrm{CO}_{2}-\mathrm{C} \mathrm{m}^{-2} \mathrm{yr}^{-1}$ or $56 \%$ but increased at Giel'cykaŭ Kašyl' by $259 \mathrm{~g} \mathrm{CO}_{2}-\mathrm{C} \mathrm{m}^{-2} \mathrm{yr}^{-1}$ or $263 \%$ compared to the first year. 
Table 2. Annual fluxes of $\mathrm{CO}_{2}, \mathrm{CH}_{4}$, and Carbon $\left(\mathrm{C}\right.$ balance $=\mathrm{NEE}+\mathrm{CH}_{4}$ emissions $)$ with $90 \%$ confidence intervals.

\begin{tabular}{|c|c|c|c|c|c|c|}
\hline Site & Year & $\begin{array}{l}R_{\mathrm{eco}} \\
\left(\mathrm{gCO}_{2}-\mathrm{Cm}^{-2} \mathrm{yr}^{-1}\right)\end{array}$ & $\begin{array}{l}\mathrm{GPP} \\
\left(\mathrm{gCO}_{2}-\mathrm{Cm}^{-2} \mathrm{yr}^{-1}\right)\end{array}$ & $\begin{array}{l}\mathrm{NEE} \\
\left(\mathrm{gCO}_{2}-\mathrm{C} \mathrm{m}^{-2} \mathrm{yr}^{-1}\right)\end{array}$ & $\begin{array}{l}\mathrm{CH}_{4} \text { emissions } \\
\left(\mathrm{g} \mathrm{CH}_{4}-\mathrm{Cm}^{-2} \mathrm{yr}^{-1}\right)\end{array}$ & $\begin{array}{l}\text { C balance } \\
\left(\mathrm{g} \mathrm{C} \mathrm{m}^{-2} \mathrm{yr}^{-1}\right)\end{array}$ \\
\hline \multirow[t]{2}{*}{ BA Eriophorum-Carex } & 1 & 364 (339 to 396$)$ & $-449(-512$ to -407$)$ & $-86(-130$ to -38$)$ & $10(9$ to 13$)$ & $-75(-114$ to -30$)$ \\
\hline & 2 & 406 (368 to 458$)$ & $-413(-449$ to -376$)$ & $-7(-49$ to 21$)$ & $11(10$ to 14$)$ & $4(-35$ to 30$)$ \\
\hline \multirow[t]{2}{*}{ BA Carex-Equisetum } & 1 & 232 (196 to 262$)$ & $-320(-361$ to -279$)$ & $-88(-114$ to -68$)$ & $17(13$ to 22$)$ & $-71(-92$ to -56$)$ \\
\hline & 2 & $327(282$ to 371$)$ & $-302(-334$ to -281$)$ & $24(-6$ to 55$)$ & $13(9$ to 16$)$ & $37(8$ to 66$)$ \\
\hline \multirow[t]{2}{*}{ BA Phragmites-Carex } & 1 & 614 (478 to 737$)$ & $-1141(-1595$ to -888$)$ & $-528(-933$ to -194$)$ & $42(28$ to 58$)$ & $-486(-873$ to -156$)$ \\
\hline & 2 & 706 (568 to 842$)$ & $-1035(-1134$ to -949$)$ & $-329(-431$ to -220$)$ & $36(22$ to 52$)$ & $-293(-377$ to -205$)$ \\
\hline \multirow[t]{2}{*}{ GK Typha-Hydrocharis } & 1 & 921 (841 to 982$)$ & $-771(-842$ to -665$)$ & $151(41$ to 300$)$ & 60 (47 to 77$)$ & $210(111$ to 360$)$ \\
\hline & 2 & $973(818$ to 1156$)$ & $-1086(-1476$ to -862$)$ & $-113(-418$ to 66$)$ & 68 (52 to 92$)$ & $-45(-343$ to 142$)$ \\
\hline \multirow[t]{2}{*}{ GK Carex-Lysimachia } & 1 & 1105 (1007 to 1207$)$ & $-940(-1081$ to -774$)$ & $166(66$ to 252$)$ & $86(63$ to 121$)$ & $252(145$ to 356$)$ \\
\hline & 2 & $1270(1221$ to 1362$)$ & $-1054(-1243$ to -789$)$ & $216(48$ to 470$)$ & $85(59$ to 142$)$ & 301 (137 to 552$)$ \\
\hline \multirow[t]{2}{*}{ GK Phragmites-Lemna } & 1 & $936(733$ to 1200$)$ & $-1547(-1726$ to -1386$)$ & $-611(-819$ to -450$)$ & $100(48$ to 147$)$ & $-516(-747$ to -349$)$ \\
\hline & 2 & 1092 (937 to 1210$)$ & $-2267(-2733$ to -1843$)$ & $-1175(-1567$ to -690$)$ & 101 (61 to 177$)$ & $-1074(-1453$ to -565$)$ \\
\hline
\end{tabular}

Uncertainties on the site level include the uncertainties of the plot models and the spatial heterogeneity. They were calculated by pooling the plot specific annual models derived by error calculation. Different $\mathrm{CO}_{2}$ balances of the $\mathrm{H}$ approach and the $\mathrm{LS}$ approach were accounted for by adding the differences randomly to $50 \%$ of the respective annual values derived by error calculation with the $\mathrm{H}$ approach. To derive uncertainties of $\mathrm{C}$ balances the annual models of $\mathrm{NEE}$ and $\mathrm{CH}_{4}$ derived by plot-wise error calculation were summarized and combined site-wise.

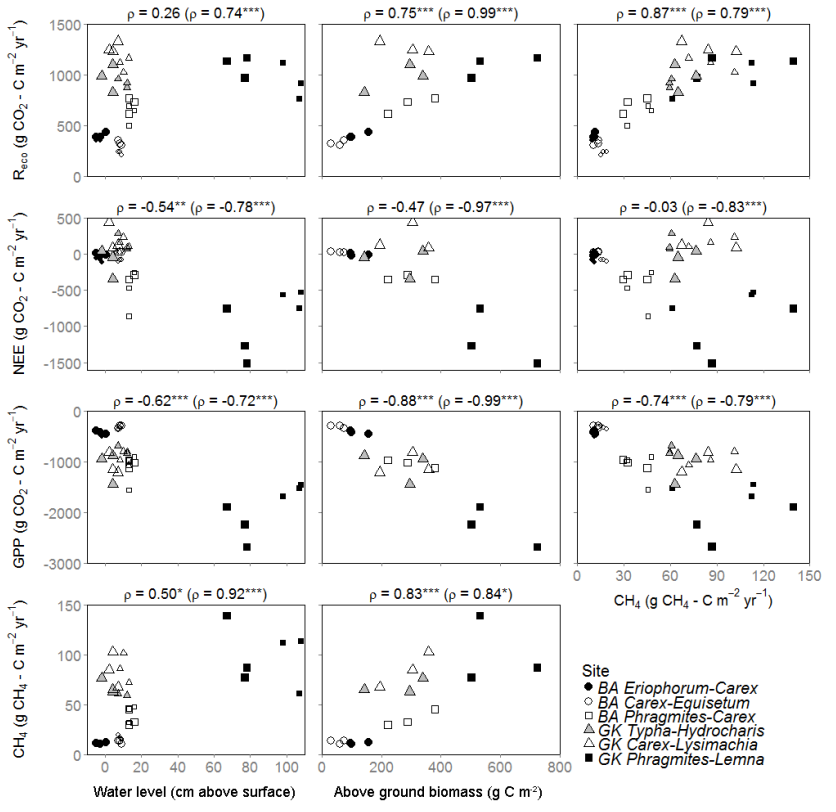

Figure 6. Scatter plots of annual NEE, $R_{\mathrm{eco}}$, GPP, $\mathrm{CH}_{4}$ emissions, median annual water levels (both years for all plots, $n=36$ ), and above-ground biomass carbon (second year for all plots, $n=18$ ). Spearman's $\rho$ significant at ' $P \leq 0.05 ;{ }^{*} P \leq 0.01$; ${ }^{* *} P \leq 0.001$; ${ }^{* * *} P \leq 0.0001$. Spearman's $\rho$ in brackets without GK TyphaHydrocharis and GK Carex-Lysimachia $(n=30$ for correlations among water levels and fluxes; $n=15$ for correlations among biomass and fluxes). Small symbols indicate first year, large symbols second year.

Small-scale spatial variability of annual NEE fluxes was largest for GK Phragmites-Lemna (187 $\pm 153 \mathrm{~g} \mathrm{CO}_{2}$ $\mathrm{C} \mathrm{m}^{-2} \mathrm{yr}^{-1}$ and mean \pm standard deviation of the absolute differences between annual plot emissions and annual site emissions, $n=6$; Table 3; Fig. 5). The absolute value of within-site spatial variability of NEE exchange rates was lower for BA Phragmites-Carex, GK Carex-Lysimachia and
GK Typha-Hydrocharis and small for BA EriophorumCarex and BA Carex-Equisetum $\left(16 \pm 13\right.$ and $9 \pm 5 \mathrm{~g} \mathrm{CO}_{2}$ $\mathrm{C} \mathrm{m}^{-2} \mathrm{yr}^{-1}$; Table 3, Fig. 5). The order of sites changes, when within site variability of NEE is related to annual site NEE fluxes. Relative variability was the same for BA Carex-Equisetum and GK Phragmites-Lemna (19 \pm 12 and $20 \pm 11 \%$, respectively, Table 3 ). This is related to the importance of the annual flux magnitude as illustrated by BA Eriophorum-Carex in the second year that resulted from an annual site $\mathrm{NEE}$ of $-7 \mathrm{~g} \mathrm{CO}_{2}-\mathrm{C} \mathrm{m}^{-2} \mathrm{yr}^{-1}$ and an absolute within site spatial variability of $11 \mathrm{~g} \mathrm{CO}_{2}-\mathrm{C} \mathrm{m}^{-2} \mathrm{yr}^{-1}$ in a relative variability of $152 \%$.

\subsection{Methane emissions}

\subsubsection{Diurnal variability of methane emissions and impact of chamber types}

Opaque and transparent chambers slightly differed in the development of air temperature and relative humidity of the headspace during the measurements. Despite cooling temperature rose more in transparent (up to $3 \pm 0.5^{\circ} \mathrm{C}$, mean \pm standard error; Table A2) than in opaque chambers (up to $1.4 \pm 0.2^{\circ} \mathrm{C}$ ). Due to cooling, however, relative humidity increased less in transparent (up to $18.1 \pm 3.7 \%$ ) than in opaque chambers (up to $14.8 \pm 2.3 \%$ ). Differences were significant at few measurement days only (Table A2).

Pronounced diurnal methane emission dynamics were observed for BA Phragmites-Carex and GK PhragmitesLemna, much stronger than for any other site (Fig. 3). Significantly different methane emissions between opaque and transparent chambers, however, were only found for GK Typha-Hydrocharis and GK Carex-Lysimachia (Table A2). Measurements with transparent chambers resulted here in 20 and $10 \%$ higher emission estimates than with opaque chambers with fan. Also for BA Eriophorum-Carex I measurements with transparent chambers produced $9 \%$ higher flux rates than opaque chambers, but the difference was not sig- 
Table 3. Small-scale spatial variability of net $\mathrm{CO}_{2}$ and $\mathrm{CH}_{4}$ emissions.

\begin{tabular}{lllll}
\hline & \multicolumn{1}{c}{$\begin{array}{c}\text { Absolute small-scale spatial variability } \\
\left(\mathrm{g} \mathrm{C} \mathrm{m}^{-2} \mathrm{yr}^{-1}\right)^{\mathrm{a}}\end{array}$} & \multicolumn{2}{c}{$\begin{array}{c}\text { Relative small-scale spatial } \\
\text { variability }(\%)\end{array}$} \\
\cline { 2 - 5 } & $\mathrm{NEE}$ & $\mathrm{CH}_{4}$ emissions & $\mathrm{NEE}$ & $\mathrm{CH}_{4}$ emissions \\
\hline BA Eriophorum-Carex & $16 \pm 13$ & $0.5 \pm 0.2$ & $89 \pm 105$ & $4 \pm 2$ \\
BA Carex-Equisetum & $9 \pm 5$ & $1.4 \pm 0.7$ & $19 \pm 12$ & $10 \pm 5$ \\
BA Phragmites-Carex & $125 \pm 140$ & $6.4 \pm 2.7$ & $25 \pm 25$ & $17 \pm 7$ \\
GK Typha-Hydrocharis & $121 \pm 66$ & $3.2 \pm 3.2$ & $97 \pm 63$ & $5 \pm 5$ \\
GK Carex-Lysimachia & $95 \pm 73$ & $10.9 \pm 8.3$ & $47 \pm 33$ & $13 \pm 10$ \\
GK Phragmites-Lemna & $187 \pm 153$ & $24.2 \pm 10.0$ & $20 \pm 11$ & $25 \pm 10$ \\
\hline
\end{tabular}

Given are means \pm standard deviations, $n=6$. $^{\text {a }}$ absolute differences between annual plot emissions and annual site emissions.

$\mathrm{b}$ Absolute differences between annual plot emissions and annual site emissions in percentages of absolute values of annual site emissions.

nificant (Fig. 3, Table A2). At all other sites the flux rates measured with transparent and opaque chambers with fan agreed within $2 \%$. The chamber intercomparison suggests a potential reduction of convective gas transport in Typha latifolia by shading with the regularly applied opaque chambers without fan. Consequently, the measured growing season fluxes from GK Typha-Hydrocharis and GK CarexLysimachia were corrected upwards by $20 \%$ as Typha latifolia was present at all plots except for GK Carex-Lysimachia I in 2012 where the diurnal chamber intercomparison took place (Table A2). Fluxes from the other sites were not corrected because chamber effects were not significant.

\subsubsection{Annual methane emissions}

The Lloyd-Taylor methane models performed well for all sites except for the second year of BA Phragmites-Carex and GK Phragmites-Lemna. NSE for all but the Phragmites australis sites ranged between 0.38 and 0.85 (median 0.58). Models of the Phragmites australis sites were acceptable in the first year (median NSE 0.37 , range 0.05 to 0.82 ) but performed worse in the second year (median 0.01 , range -0.25 to 0.24 ), where models did not adequately capture the seasonal course of methane emissions at three out of six Phragmites plots. Models of GK Phragmites-Lemna III and BA Phragmites-Carex III did not explain the high emissions in August 2011 (Figs. 4h and s). Both mentioned models and the model of BA Phragmites-Lemna I overestimated emissions in spring and early summer 2012. Annual emissions were calculated alternatively by linear interpolation for the second year of BA Phragmites-Lemna I and III and GK Phragmites-Lemna III. The resulting flux rates of 25, 28, and $118 \mathrm{~g} \mathrm{CH}_{4}-\mathrm{C} \mathrm{m}^{-2} \mathrm{yr}^{-1}$ lie within the $90 \%$ confidence intervals of the temperature driven Lloyd-Taylor methane model (30, 32, and $139 \mathrm{~g} \mathrm{CH}_{4}-\mathrm{C} \mathrm{m}^{-2} \mathrm{yr}^{-1}$; Table A3). The LloydTaylor models were therefore accepted despite of negative NSE.

GK Phragmites-Lemna had the highest methane emissions of all sites, estimated to 100 (90\% confidence inter- val 48,147$)$ and $101(61,177) \mathrm{g} \mathrm{CH}_{4}-\mathrm{C} \mathrm{m}^{-2} \mathrm{yr}^{-1}$ in the first and second year, respectively, (Table 2). GK CarexLysimachia released less methane. GK Typha-Hydrocharis was the smallest source among the studied sites at Giel'cykaŭ Kašyl' with $60(47,77)$ and $68(52,92) \mathrm{g} \mathrm{CH}_{4}-\mathrm{C} \mathrm{m}^{-2} \mathrm{yr}^{-1}$, but still larger than the Barcianicha sites.

BA Phragmites-Carex emitted $42(28,58)$ in the first and $36(22,52) \mathrm{g} \mathrm{CH}_{4}-\mathrm{C} \mathrm{m}^{-2} \mathrm{yr}^{-1}$ in the second year. BA Carex-Equisetum was a much smaller methane source, but the absolute lowest annual methane emissions were found at BA Eriophorum-Carex being $10(9,13)$ in the first and 11 $(10,14) \mathrm{g} \mathrm{CH}_{4}-\mathrm{C} \mathrm{m}^{-2} \mathrm{yr}^{-1}$ in the second year (Table 2).

Methane emissions of all sites hardly differed between years (Table 2). They decreased in the second year at Barcianicha by on average $3 \mathrm{~g} \mathrm{CH}_{4}-\mathrm{C} \mathrm{m}^{-2} \mathrm{yr}^{-1}$ or $14 \%$ but increased at Giel'cykaŭ Kašyl' by $4 \mathrm{~g} \mathrm{CH}_{4}-\mathrm{C} \mathrm{m}^{-2} \mathrm{yr}^{-1}$ or $5 \%$ compared to the first year.

Absolute and relative small-scale variability of methane emissions tended to increase with annual methane emission height (Fig. 5, Table 3).

\subsection{Nitrous oxide emissions}

Emissions of $\mathrm{N}_{2} \mathrm{O}$ from all plots were around zero (Fig. 5e and f). Maximum plot emissions were around $0.5 \mathrm{~g} \mathrm{~N}_{2} \mathrm{O}-\mathrm{N}$ $\mathrm{m}^{-2} \mathrm{yr}^{-1}$, but were usually compensated for by similar large uptakes in a neighbour plot or the other year. The overlap of the $90 \%$ confidence of all sites, plots and years indicates that $\mathrm{N}_{2} \mathrm{O}$ emissions were not significantly different among them.

\subsection{Correlations between annual GHG emissions and site parameters}

GHG emissions were only weakly related to surface peat characteristics. Spearman's $\rho$ of the correlation between annual methane emissions and $\mathrm{C} / \mathrm{N}$ ratio was $-0.50^{*}$ and between annual net $\mathrm{CO}_{2}$ exchange and $\mathrm{pH} 0.40$ ' ' $P \leq 0.05$; ${ }^{*} P \leq 0.01, n=36$, i.e. correlation of peat characteristics of 
Table 4. GHG balances based on the global warming potentials of $\mathrm{CO}_{2}, \mathrm{CH}_{4}$ and $\mathrm{N}_{2} \mathrm{O}$ for a time horizon of $100 \mathrm{yr}\left(\mathrm{GWP}_{100}\right.$ of $\mathrm{CO}_{2}=1$, of $\mathrm{CH}_{4}=28$ and of $\mathrm{N}_{2} \mathrm{O}=265 \mathrm{CO}_{2}$-equivalents, Myhre et al., 2013) with $90 \%$ confidence intervals.

\begin{tabular}{|c|c|c|c|c|c|}
\hline Site & Year & 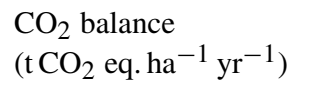 & $\begin{array}{l}\mathrm{CH}_{4} \text { balance } \\
\left(\mathrm{tCO}_{2} \text { eq. ha }{ }^{-1} \mathrm{yr}^{-1}\right)\end{array}$ & $\begin{array}{l}\mathrm{N}_{2} \mathrm{O} \text { balance } \\
\left(\mathrm{tCO}_{2} \text { eq. ha }{ }^{-1} \mathrm{yr}^{-1}\right)\end{array}$ & 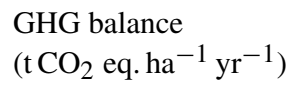 \\
\hline BA Eriophorum-Carex & 1 & $-3.1(-4.8$ to -1.4$)$ & $3.8(2.9$ to 5.0$)$ & $-0.1(-0.8$ to 0.8$)$ & $0.5(-1.4$ to 3.1$)$ \\
\hline \multirow[t]{2}{*}{ BA Carex-Equisetum } & 1 & $-3.2(-3.2$ to -2.5$)$ & $6.4(5.0$ to 8.0$)$ & $-0.1(-0.7$ to 0.5$)$ & $3.1(1.9$ to 5.0$)$ \\
\hline & 2 & $0.9(-0.2$ to 2.1$)$ & $4.7(3.2$ to 6.1$)$ & $-0.3(-0.9$ to 0.2$)$ & $5.3(3.3$ to 7.3$)$ \\
\hline BA Phragmites-Carex & 1 & $-19.4(-34.2$ to -7.1$)$ & $15.6(10.4$ to 21.6$)$ & $-0.3(-2.9$ to 3.0$)$ & $-4.1(-16.9$ to 11.9$)$ \\
\hline GK Typha-Hydrocharis & 2 & $-4.2(-15.3$ to 2.4$)$ & $25.5(19.3$ to 34.4$)$ & $0.4(-0.7$ to 1.5$)$ & $21.7(7.6$ to 36.1$)$ \\
\hline \multirow[t]{2}{*}{ GK Carex-Lysimachia } & 1 & $6.1(2.4$ to 9.2$)$ & $32.3(23.6$ to 45.5$)$ & $-0.1(-2.1$ to 1.8$)$ & $38.2(27.8$ to 53.7$)$ \\
\hline & 2 & $7.9(1.8$ to 17.2$)$ & $31.6(22.2$ to 53.1$)$ & $0.4(-0.8$ to 1.9$)$ & $39.9(25.8$ to 60.7$)$ \\
\hline \multirow{2}{*}{ GK Phragmites-Lemna } & 1 & $-22.4(-30.0$ to -16.5$)$ & 35.7 (18.0 to 54.7$)$ & $0.6(-2.4$ to 3.8$)$ & $13.9(-10.6$ to 36.0$)$ \\
\hline & 2 & $-43.1(-57.5$ to -25.3$)$ & 37.7 (22.9 to 66.2$)$ & $0.0(-3.5$ to 3.4$)$ & $-5.4(-29.2$ to 40.0$)$ \\
\hline
\end{tabular}

Confidence intervals include the uncertainties of the plot models and the spatial heterogeneity. To derive uncertainties of $\mathrm{GHG}$ balances the annual models of $\mathrm{CO}_{2}(\mathrm{NEE}), \mathrm{CH}_{4}$ and $\mathrm{N}_{2} \mathrm{O}$ derived by plot-wise error calculation were summarized and combined site-wise.

18 plots with annual fluxes of these plots of two GHG measuring years).

Median annual water level was not correlated with $R_{\text {eco }}$, but with NEE and $\mathrm{CH}_{4}$ emissions and most strongly with GPP (Fig. 6). Correlations of water levels with $R_{\mathrm{eco}}$, GPP, $\mathrm{NEE}$ and $\mathrm{CH}_{4}$, were highly significant when the floating sites GK Typha-Hydrocharis and GK Carex-Lysimachia were excluded from the analysis (Fig. 6, $\rho$ in brackets). Correlations of water level with $\mathrm{NEE}$ and $\mathrm{CH}_{4}$ were also strong for Barcianicha alone $\left(\rho=-0.60^{* *}, 0.85^{* * *}\right.$, respectively, ${ }^{* *} P \leq 0.001$; $\left.{ }^{* * *} P \leq 0.0001, n=18\right)$.

Total above-ground biomass carbon harvested after the second measuring year strongly correlated with the second year annual balances of $\mathrm{CH}_{4}, R_{\text {eco }}$ and GPP, but not with NEE (Fig. 6). Without the floating tall sedge - Typha latifolia sites correlations between biomass and balances of $R_{\text {eco }}$ and GPP were stronger and the correlation between biomass and NEE became highly significant. When only Barcianicha was analysed, correlation between biomass and methane emissions were not significant, but correlations between biomass and $R_{\mathrm{eco}}$, GPP, and NEE were strong ( $\rho=0.98^{* * *},-0.98^{* * *},-0.95^{* *}$, respectively, $n=9$ ).

Annual $\mathrm{CH}_{4}$ emissions did not correlate with annual NEE, but strongly with $R_{\text {eco }}$ and GPP (Fig. 6). Excluding GK Typha-Hydrocharis and GK Carex-Lysimachia resulted in highly significant correlation between methane and NEE (Fig. 6, $\rho=-0.83, P<0.0001, n=30$ ). For Barcianicha alone correlation between NEE and $\mathrm{CH}_{4}$ emissions was also significant $(\rho=-0.67, P=0.0028, n=18)$.

As expected, within-site variation of $R_{\text {eco }}$ and absolute GPP generally scaled with biomass (Fig. 6). Methane emissions increased among plots of BA Phragmites-Carex with increasing absolute GPP and $R_{\text {eco }}$ and all three fluxes were positively correlated with above-ground biomass. A posi- tive correlation between biomass and methane also occurred for GK Carex-Lysimachia, while at GK Phragmites-Lemna methane emissions tended to decrease with increasing net $\mathrm{CO}_{2}$ uptake (Fig. 6).

\subsection{Carbon and GHG-balances of sites}

Both Phragmites sites were surprisingly strong carbon sinks (Table 2) but also methane sources and had only low net GHG emissions with an overall mean of $1.3 \mathrm{tCO}_{2}$ eq. ha ${ }^{-1}$ yr. The 2-year average GHG balances of the shallowly flooded, mesotrophic site BA Phragmites-Carex and the deeply inundated, eutrophic site GK Phragmites-Lemna were - 1.7 (90\% confidence interval $-15.0,10.2)$ and $4.2(-26.8,37.7) \mathrm{tCO}_{2}$ eq. $\mathrm{ha}^{-1} \mathrm{yr}^{-1}$, respectively. The mesotrophic small sedge reeds BA Eriophorum-Carex and BA Carex-Equisetum with water tables around the land surface were weak carbon sinks and methane sources (Table 2). Both sites were small net GHG emitters of $2.3(-1.0,5.6)$ and $4.2(2.1,6.8)$ $\mathrm{tCO}_{2}$ eq. ha $\mathrm{yr}^{-1} \mathrm{yr}^{-1}$, respectively. The eutrophic, floating tall sedge - Typha latifolia reeds were, despite of shallow relative water depths, strong methane sources and in most years also net $\mathrm{CO}_{2}$ emitters. GK Typha-Hydrocharis was a substantial GHG source of $25.1(9.5,37.9) \mathrm{tCO}_{2}$ eq. $\mathrm{ha}^{-1} \mathrm{yr}^{-1}$ and GK Carex-Lysimachia even emitted 39.1 (26.6, 58.0) $\mathrm{tCO}_{2}$ eq. ha ${ }^{-1} \mathrm{yr}^{-1}$.

The role of $\mathrm{N}_{2} \mathrm{O}$ exchange was negligible for the GHGbalances of all sites. 


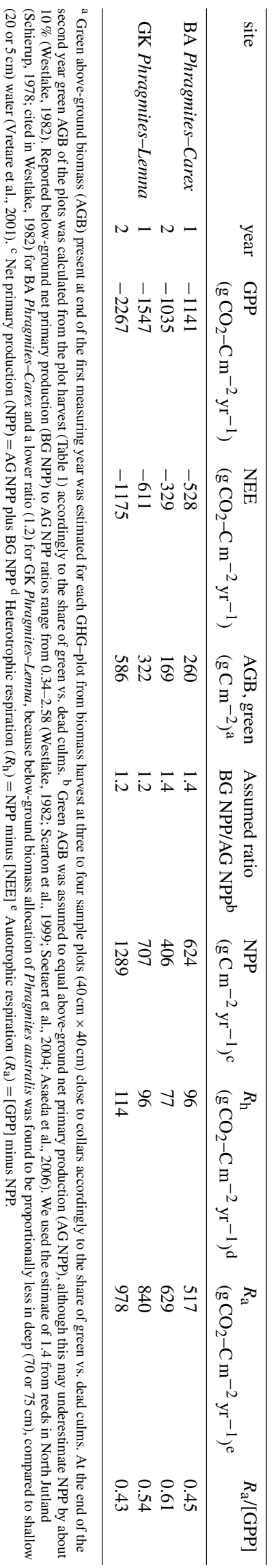

\section{Discussion}

\subsection{Annual $\mathrm{CO}_{2}$ and methane balances}

Contrary to our hypothesis (i) only three sites were stable net $\mathrm{CO}_{2}$ sinks, two sites switched between sink and source and one site was a net $\mathrm{CO}_{2}$ source in both years. Surprisingly, both eutrophic tall sedge - Typha latifolia reeds on newly formed floating mats were net $\mathrm{CO}_{2}$ sources over the 2-year period although the mats suggest a net carbon accumulation since rewetting.

For all site years with a net $\mathrm{CO}_{2}$ sink we can argue in line with hypothesis (i) that peat loss by oxidation has stopped after rewetting. We suggest that also in site years with a net $\mathrm{CO}_{2}$ source the $\mathrm{CO}_{2}$ loss originated from decaying plant material rather than from peat. All source sites were fully watersaturated throughout the year and had substantial methane emissions, indicating fully anaerobic conditions. We suggest that the $\mathrm{CO}_{2}$ originated from accumulated plant litter or from high stress related plant respiration as the sites where $\mathrm{CO}_{2}$ sources occurred were characterized by transitional vegetation stages (see below).

The $\mathrm{CO}_{2}$ and methane balances of the mesotrophic small sedge reeds at Barcianicha agree with the literature. Eutrophic tall sedge - Typha latifolia reeds on newly formed floating mats have not been studied before but results generally agree with literature from eutrophic mineral reed ecosystems. The Phragmites reeds also agree with literature with regard to the methane emissions, but have an exceptionally strong $\mathrm{CO}_{2}$ sink. In the following details are discussed for the three site groups.

Annual methane emissions from BA Eriophorum-Carex and BA Carex-Equisetum were of the same magnitude as from similar small sedge reeds in two rewetted cutover Atlantic bogs (Wilson et al., 2009, 2013). Net uptake and net release of $\mathrm{CO}_{2}$, however, was smaller for BA EriophorumCarex and BA Carex-Equisetum as compared to the mentioned Irish sites (Wilson et al., 2007, 2013; Table 6), perhaps partly resulting from lower productivity.

Methane emissions from BA Phragmites-Carex compared well to the shallow water inner reed zone $\left(33 \mathrm{~g} \mathrm{CH}_{4}-\mathrm{Cm}^{-2} \mathrm{yr}^{-1}\right)$ and that from $\mathrm{GK}$ Phragmites-Lemna to the deep water outer reed zone $\left(122 \mathrm{~g} \mathrm{CH}_{4}-\mathrm{C} \mathrm{m}^{-2} \mathrm{yr}^{-1}\right)$ of lake Lake Vesijärvi in southern Finland (Table 6; Kankaala et al., 2004). Methane emissions from a Phragmites australis dominated, shallowly inundated marsh in north-central Nebraska, USA $\left(60 \mathrm{~g} \mathrm{CH}_{4}-\mathrm{C} \mathrm{m}^{-2} \mathrm{yr}^{-1}\right.$; Kim et al., 1998) as well as from wet Phragmites australis stands in a rewetted Dutch fen ( 88 $\mathrm{g} \mathrm{CH}_{4}-\mathrm{C} \mathrm{m}^{-2} \mathrm{yr}^{-1}$; Hendriks et al., 2007) were between both Phragmites reeds of the present study. Annual NEE fluxes of both Phragmites australis sites were more than 10 times higher than at a freshwater tidal reed wetland in NE China, though above-ground biomass was comparable (Zhou et al., 2009). The differences result from smaller 


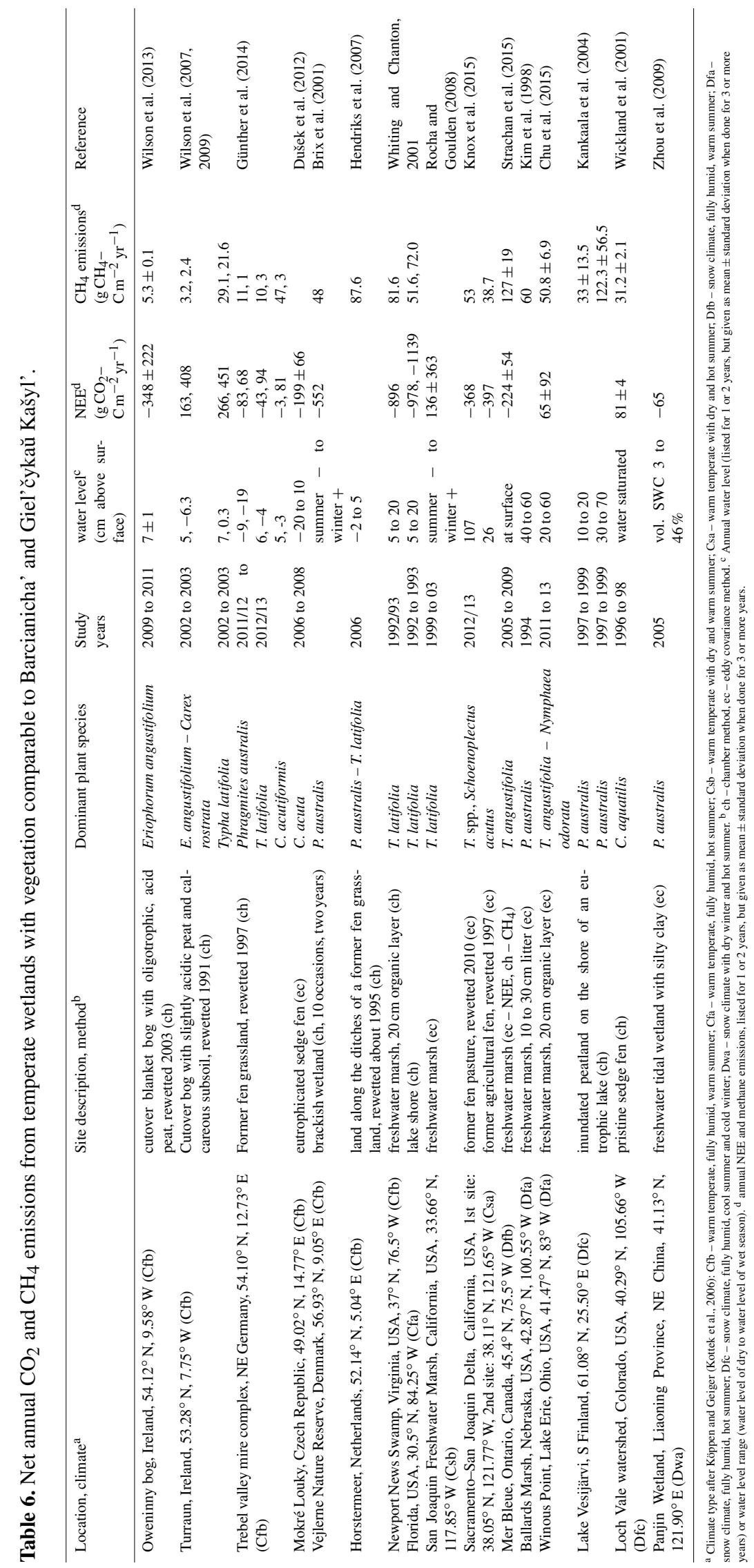


ratios of $R_{\text {eco }}$ to GPP in the present $(0.58 \pm 0.09, n=4)$ compared to the tidal reed study $(0.95)$ and can be explained by permanent inundation of BA Phragmites-Carex and GK Phragmites-Lemna, and consequently low heterotrophic respiration, while the soil of the tidal reed wetland was periodically aerated. The importance of water level was also evident for a Phragmites australis site in a rewetted former grassland fen in NE Germany that sequestrated $83 \mathrm{~g} \mathrm{CO}_{2}-\mathrm{C} \mathrm{m}^{-2} \mathrm{yr}^{-1}$ and emitted $11 \mathrm{~g} \mathrm{CH}_{4}-\mathrm{Cm}^{-2} \mathrm{yr}^{-1}$ in an exceptionally wet year (WL at surface) but released $68 \mathrm{~g} \mathrm{CO}_{2}-\mathrm{C} \mathrm{m}^{-2} \mathrm{yr}^{-1}$ and only $1 \mathrm{~g} \mathrm{CH}_{4}-\mathrm{Cm}^{-2} \mathrm{yr}^{-1}$ in a typical year (WL below surface; Günther et al., 2014).

Annual methane and $\mathrm{CO}_{2}$ fluxes from floating tall sedge - Typha latifolia reeds are not reported in the literature. Methane emissions from GK Typha-Hydrocharis and GK Carex-Lysimachia were higher compared to a pristine, water saturated sedge fen (dominated by Carex aquatilis) in the southern Rocky Mountains (30 to $34 \mathrm{~g} \mathrm{CH}_{4}-\mathrm{C} \mathrm{m}^{-2} \mathrm{yr}^{-1}$; Table 6; Wickland et al., 2001) or to Carex acutiformis and Typha latifolia sites during the wet year in the above mentioned rewetted fen grassland (47 and $10 \mathrm{~g} \mathrm{CH}_{4}-\mathrm{C} \mathrm{m}^{-2} \mathrm{yr}^{-1}$, respectively; Günther et al., 2014). They were comparable to temperate Typha latifolia $\left(82 \mathrm{~g} \mathrm{CH}_{4}-\mathrm{C} \mathrm{m}^{-2} \mathrm{yr}^{-1}\right.$; Whiting and Chanton, 2001) and $T$. angustifolia marshes $\left(51 \mathrm{~g} \mathrm{CH}_{4}-\mathrm{C} \mathrm{m}^{-2} \mathrm{yr}^{-1}\right.$, Chu et al., 2015; $127 \mathrm{~g} \mathrm{CH}_{4}-\mathrm{C} \mathrm{m}^{-2} \mathrm{yr}^{-1}$, Strachan et al., 2015). The constantly high water levels made us expect a net $\mathrm{CO}_{2}$ uptake at GK Typha-Hydrocharis and GK CarexLysimachia, as was found for Typha latifolia and T. angustifolia marshes (Whiting and Chanton, 2001; Strachan et al., 2015), for a water saturated temperate sedge fen in the Czech Republic (Dušek et al., 2012), and in the wet year for Carex acutiformis and Typha latifolia (Günther et al., 2014). However, in contrast to our first hypothesis the sites GK Typha-Hydrocharis and GK Carex-Lysimachia were net $\mathrm{CO}_{2}$ sources. Similar, a wet sedge fen in the southern Rocky Mountains (Wickland et al., 2001) and a water saturated Typha angustifolia marsh (Chu et al., 2015) were found to be $\mathrm{CO}_{2}$ sources (Table 6). Chu et al. (2015) explain their findings by abnormal climatic conditions. As climatic conditions during the first year of the present study were similar to the long term average, other factors, like reduced GPP because of shading from old standing leaves (Rocha et al., 2008) may have been important, as there was much dry biomass present. Also the high water levels and their strong fluctuations may have imposed stress on the vegetation (Dušek et al., 2012), as indicated by changes in the cover of the dominant species between years (Table A1) and the early aging of the sedges. High $R_{\text {eco }}$ fluxes from the floating tall sedge - Typha latifolia reeds could be the result of increased maintenance respiration because of environmental stress (Chapin et al., 2002) combined with high heterotrophic respiration from decomposing dead plant material which formed the main part of the sedge tussocks (estimated from photographic documentation). This indicates that the plant communities were not well adapted to the present conditions and represent a transient development stage.

\subsection{Robustness of annual GHG balances}

\subsubsection{Methane}

Overall, our measurement design and data treatment produces annual methane balances at the high end of the expected real fluxes.

The pronounced diurnal methane emission dynamics from BA Phragmites-Carex and GK Phragmites-Lemna with 5fold flux increases from morning to midday result from active air transport in Phragmites australis aerenchyma in the growing season driven by sun light (Armstrong and Armstrong, 1991; Brix et al., 1992; Armstrong et al., 1996). In contrast to other studies (Van der Nat and Middelburg, 2000; Günther et al., 2013) we did not find a significant impact of chamber transparency on measured methane emission rates, maybe because enclosed plants were connected by rhizomes with culms outside the chamber. Such connection seems to allow for pressure propagation and continuation of unrestrained convective gas flow (Juutinen et al., 2004; Minke et al., 2014). Consequently the application of opaque chambers has not biased annual emission estimates from the Phragmites australis sites.

Day-to-day variability and seasonal variation of average daily emissions from Phragmites australis stands are controlled by sediment temperature (Kim et al., 1998; Kankaala et al., 2004), which supports our decision to use soil temperature for modelling methane emissions. However, a single measurement at any time during daylight does not represent the daily emission average. For the monitored days (Fig. 3) most measurements between 9.00 and 18.00 Moscow standard time resulted in equal or higher estimates as compared to the $24 \mathrm{~h}$ mean. Our daylight measurements during the growing period slightly overestimate the daily methane flux rates. In summary, our approach tended to overestimate the real emissions at the Phragmites australis sites.

GK Typha-Hydrocharis showed less pronounced diurnal methane emission dynamics (Fig. 3). Unlike Phragmites, Typha latifolia reacted on shading. The reduction of emissions by opaque chambers agrees with other studies of Typha latifolia (Chanton et al., 1993; Whiting and Chanton, 1996). Similar to Phragmites australis, green parts of Typha latifolia pressurize during daylight which drives convective gas transport and accelerates methane efflux (Brix et al., 1992; Whiting and Chanton, 1996). Obviously, Typha latifolia plants are less connected than Phragmites and cannot compensate for small-scale shading during chamber deployment. Our transparent/opaque ratios of measured methane flux rates of 1.2 agrees with previous studies for Typha latifolia (1.1 - Whiting and Chanton, 1996; 1.3 - Günther et al., 2013). However, we do not know the variability of the ratio under different weather conditions. We applied the correction factor 1.2 for 
total daily methane emissions during the growing season, although chamber transparency only matters during daylight. Estimated annual emissions will consequently be at the high end of real emissions from the site.

Methane measurements were significantly affected by shading at the floating Carex elata plot, but not at the small sedge plots dominated by Carex rostrata and Eriophorum angustifolium. Gas transport in sedges is driven only by diffusion (Armstrong, 1979; King et al., 1998). Existing studies were ambiguous regarding the effect of shading by chambers. Shading reduced methane emissions from Carex aquatilis (Morrissey et al., 1993) and Carex allivescers (Hirota et al., 2004), but not from Carex limosa and Carex rostrata (Whiting and Chanton, 1992), Carex acutiformis (Günther et al., 2013) and Eriophorum angustifolium (Joabsson et al., 1999; Whiting and Chanton, 1992).

\subsubsection{Carbon dioxide}

The two approaches used to model $\mathrm{CO}_{2}$ exchange rates resulted in very similar annual balances. Plot-wise annual $R_{\text {eco }}$ calculated with the $\mathrm{H}$ approach was on average $5 \pm 5 \%$ (mean \pm standard deviation, $n=36$ ) below the LS approach, while GPP sink was $1 \pm 3 \%(n=36)$ higher. Resulting annual net $\mathrm{CO}_{2}$ uptake was consequently on average stronger for the $\mathrm{H}$ approach than for the LS approach. The mean difference of NEE between both approaches was $43 \pm 41 \mathrm{~g} \mathrm{CO}_{2}-\mathrm{C} \mathrm{m}^{-2} \mathrm{yr}^{-1} \quad(n=36)$. This indicates that measured fluxes and general modelling assumptions, i.e. the temperature relation of $R_{\mathrm{eco}}$ and PAR relation of GPP were robust towards differences in flux calculation and model parameterization. Also the good results of the cross validations of the models of the $\mathrm{H}$ approach at all sites indicate a high robustness of the results.

The net annual $\mathrm{CO}_{2}$ sink of the Phragmites australis sites was surprisingly large, especially at GK Phragmites-Lemna. The first year NEE of this site agreed with the estimate of Brix et al. (2001; Table 6) but the second year uptake was twice as high. To test for plausibility we roughly estimated the carbon flux partitioning in the ecosystem from independent data. Based on dry weight of green above-ground biomass assessed at the end of the growing seasons 2011 and 2012 and on published ratios between above-ground and below-ground biomass production we estimated the net annual primary production (NPP, $\mathrm{g} \mathrm{C} \mathrm{m}^{-2} \mathrm{yr}^{-1}$ ) of the Phragmites australis sites during both GHG measurement periods (Table 5). Using NPP, NEE, and GPP we estimated heterotrophic and autotrophic respiration $\left(R_{\mathrm{h}}\right.$ and $R_{\mathrm{a}}$, Table 5) and evaluated their meaningfulness. As expected because of inundation, heterotrophic respiration was low, ranging between 77 and $114 \mathrm{~g} \mathrm{CO}_{2}-\mathrm{C} \mathrm{m}^{-2} \mathrm{yr}^{-1}$. The ratios of heterotrophic respiration to methane emissions $\left(\mathrm{CO}_{2}-\mathrm{C} / \mathrm{CH}_{4}-\right.$ C) were 2.2 and 2.3 in the first and second year, respectively, for BA Phragmites-Carex and closer, 1.0 and 1.1, for GK Phragmites-Lemna. Similar ratios were found in incubation experiments for organic bottom sediments and the upper peat layer of a flooded former fen grassland (Hahn-Schöfl et al., 2011). Calculated autotrophic respiration was half of GPP, but differed considerably between years (43 to $61 \%$ ). This range is plausible given the uncertainty of the underlying estimates (especially of NPP), as the efficiency of converting GPP to NPP is generally assumed to be relatively constant (cf. Chapin et al., 2002). In summary, the carbon partitioning test was plausible and supports the exceptional net $\mathrm{CO}_{2}$ uptake in the Phragmites sites. Such uptake may be explained by strong rhizome formation in a relatively young reed ecosystem but may not represent a long-term equilibrium.

\subsection{Controls of annual GHG emissions}

Reality proved more complex than our hypotheses. We studied transient vegetation development stages after fen rewetting, which may not necessarily be generalized to equilibrium stages. The findings related to the hypotheses are as follows.

The annual $\mathrm{CO}_{2}$ balance was best explained by vegetation biomass, which includes the role of vegetation composition and species. Phragmites reeds were by far the most productive ecosystems at both studied peatlands. The nutrient status affected productivity, but species effects dominated the $\mathrm{CO}_{2}$ balance. Inundation depth had no systematic effect on the annual $\mathrm{CO}_{2}$ balance.

Methane emissions were site specific. They increased with productivity and correlated strongly with $R_{\text {eco }}$ fluxes. Methane was obviously most driven by biological activity of vegetation and soil organisms. Continuously inundated sites tended to have higher methane emissions than sites where water levels remained near the land surface.

Under mesotrophic conditions rewetting leads to stable small net GHG sources or even sinks because methane emissions are largely balanced by the net $\mathrm{CO}_{2}$ sink. Under eutrophic conditions, rewetted fens remain net GHG sources in most cases. Vegetation types can be sinks or sources of $\mathrm{CO}_{2}$ and emit substantial amounts of methane so that rewetting effects on the GHG balance remain difficult to predict.

We reject, however, that the $\mathrm{CO}_{2}$ sink and methane emissions peak under shallow inundation. In contrast, the various vegetation types with shallow water showed strongly diverging $\mathrm{CO}_{2}$, methane and GHG balances in a small water level range.

The high GHG emissions from the floating tall sedge - Typha latifolia reeds are comparable to deep-drained temperate fen grassland (26 t CO 2 eq. ha ${ }^{-1} \mathrm{yr}^{-1}$ - Drösler et al., 2014; $65 \mathrm{tCO}_{2}$ eq. $\mathrm{ha}^{-1} \mathrm{yr}^{-1}$ - Eickenscheidt et al., 2015). In contrast to the other sites of the present study, important targets of peatland rewetting, i.e. restoration of the carbon sink function and reduction of GHG emissions have not been achieved for GK Typha-Hydrocharis and GK Carex-Lysimachia. 
In the following we discuss the background for the revision of the hypotheses, reasons for the differences among sites and the individual drivers of the GHG fluxes.

\subsubsection{Water table}

In a meta-analysis Blain et al. (2014) found that methane emissions from boreal and temperate, undrained and rewetted peatlands tend to increase but the $\mathrm{CO}_{2}$ sink to decrease along a water level gradient from $30 \mathrm{~cm}$ below to $20 \mathrm{~cm}$ above surface. The water level in our study ranged from $3 \mathrm{~cm}$ below to $104 \mathrm{~cm}$ above surface with most sites within $10 \mathrm{~cm}$ water table range. The diverse vegetation types with roughly similar water table had widely diverging $\mathrm{CO}_{2}$, methane and GHG balances that we cannot confirm any trend. In drained peatlands water table position defines the depth of the aerobic zone and consequently the rate of peat oxidation (Blain et al., 2014; Couwenberg et al., 2011). The sites of the present study, however, were permanently water saturated and water levels affect $\mathrm{CO}_{2}$ fluxes most likely indirectly via other controlling factors, for example vegetation composition. Methane emissions under flooded conditions are hardly affected by water table position (Blain et al., 2014). When aerenchymous plants are abundant, as in the present study, they dominate the gas exchange and methane bypasses the oxygenated water column (Whiting and Chanton, 1992; Chanton and Whiting, 1995). In analogy to $\mathrm{CO}_{2}$, water level has affected methane emissions of the studied sites mainly indirectly by vegetation composition and the type and abundance of aerenchymous plants.

Near-zero nitrous oxide emissions at all sites agree with other studies from rewetted fens with permanent water saturation (Hendriks et al., 2007; Wilson et al., 2013).

\subsubsection{Nutrient conditions}

The different nutrient status of the studied peatlands cannot be explained by surface peat properties, which were both eutrophic, but by water supply (river and grassland drainage water for Giel'cykaŭ Kašyl', groundwater for Barcianicha). Eutrophic conditions supported the establishment of more productive plant species at Giel'cykaŭ Kašyl' compared to the mesotrophic Barcianicha, higher productivity of Phragmites australis and higher microbial activity indicated by higher $R_{\text {eco }}$ and methane fluxes. This is in line with Blain et al. (2014) who found that methane and $\mathrm{CO}_{2}$ emissions are higher from rich temperate rewetted fens as compared to poor fens and bogs. Our results indicate that rich temperate rewetted fens may be further subdivided into mesotrophic and eutrophic to account for significantly different methane emissions.

\subsubsection{Vegetation and plant productivity}

Plant productivity was the main control of $\mathrm{CO}_{2}$ fluxes, as indicated by the strong correlation between biomass and NEE for all sites except GK Typha-Hydrocharis and GK CarexLysimachia (Fig. 6). However, also differences of methane emissions within sites increased with above-ground biomass and GPP (Fig. 6), and were larger in Giel'cykaŭ Kašyl' compared to Barcianicha, and in both peatlands for the Phragmites australis sites (Table 3). This is most likely due to control of vegetation and plant productivity on methane emissions, as indicated by the highly significant correlation between methane emissions and biomass, and can be explained by supply of organic material and by plant mediated gas exchange (Whiting and Chanton, 1993; Chanton et al., 1995; Bellisario et al., 1999; Whalen, 2005).

Fresh organic substrates were rather limited at Barcianicha, as indicated by the thin layer of litter and many bare peat patches. More emissions can be expected when more litter accumulates (Waddington and Day, 2007). Plant litter was more abundant at Giel'cykaŭ Kašyl', certainly because of higher plant productivity, but also because of a longer period since rewetting and deeper inundation. This may explain why a strong correlation between NEE and methane emissions was found at Barcianicha, but not at Giel'cykaŭ Kašyl'. Methane production did not only depend on actual primary production, especially in the floating tall sedge - Typha latifolia reeds of Giel'cykaŭ Kašyl'. Methane emissions from GK Typha-Hydrocharis and GK Carex-Lysimachia were high and, similar to the large $R_{\text {eco }}$ fluxes, at least partly fuelled by old litter. Also allochthonous carbon can not be excluded as a substrate for methane production at Giel'cykaŭ Kašyl' (Chu et al., 2015), for example from floating plants like Lemna trisulca that form detritus with a much higher methane production potential compared to Phragmites australis litter (Kankaala et al., 2003).

The zone of floating mats will most likely continue for many years to emit large amounts of methane and only a shift towards Phragmites australis dominated plant communities with larger $\mathrm{CO}_{2}$ sink potentials seems to allow for reduction of GHG emissions. Such a shift may not be unlikely, because Phragmites australis is growing on most of the area of Giel'cykaŭ Kašyl' and has been abundant at GK TyphaHydrocharis and GK Carex-Lysimachia in former times, as indicated by macrofossils in the peat profile (Table 1).

\section{Conclusions}

The eutrophic peatland Giel'cykaŭ Kašyl' with deep standing water had a large carbon sink potential, but also a high risk of local net $\mathrm{CO}_{2}$ losses. The site varied spatially and temporally between being a small net GHG sink and a large GHG source because of high methane emissions. The mesotrophic peatland Barcianicha with shallow, constant water levels, in contrast, constituted a smaller but more stable carbon sink and only a small GHG source. Both net $\mathrm{CO}_{2}$ uptake and methane emissions were strongly linked to vegetation and plant productivity, which in turn were related to 
water level and nutrient conditions. Emission variability increased with productivity of sites. This implies that the formulation of robust emission factors for high-productive vegetation types and mire ecosystems requires more long-term and spatially resolved GHG emission studies than for lowproductive ones.

Unexpectedly high carbon losses and GHG emissions from the floating tall sedge - Typha latifolia reeds of Giel'cykaŭ Kašyl' were most likely caused by vegetation suffering from high and strongly fluctuating water levels. The exact sources of these high emissions, as well as the duration and successional pathway of the supposed transitional phase require further investigation.
Our study indicates that permanent, shallow inundation of cutover temperate fens is a suitable measure to arrive at low GHG emissions. Phragmites australis establishment should be promoted in deeper flooded areas and will lead to comparably moderate, but variable GHG emissions or even occasional sinks. The study supports previous findings for rewetted peatlands that the risk of high GHG emissions is higher for eutrophic than mesotrophic peatlands. In spite of the possible high emissions in some vegetation types or years, flooding of eutrophic fens still represents a safe GHG mitigation option for temperate fens because even the hotspot of our study, the eutrophic floating mats, did not exceed typical GHG emissions from drained fen grasslands and the spatially dominant flooded Phragmites australis reed emitted by far less GHG than drained fens. 


\section{Appendix A}

Table A1. Plant species cover of GHG measuring plots in summer 2010 and 2012.

\begin{tabular}{|c|c|c|c|c|c|c|c|c|c|c|c|c|c|c|c|c|c|c|}
\hline \multirow[b]{3}{*}{ Species } & \multicolumn{6}{|c|}{ BA Eriophorum-Carex } & \multicolumn{6}{|c|}{ BA Carex-Equisetum } & \multicolumn{6}{|c|}{ BA Phragmites-Carex } \\
\hline & \multicolumn{3}{|c|}{2010} & \multicolumn{3}{|c|}{2012} & \multicolumn{3}{|c|}{2010} & \multicolumn{3}{|c|}{2012} & \multicolumn{3}{|c|}{2010} & \multicolumn{3}{|c|}{2012} \\
\hline & I & II & III & I & II & III & I & II & III & I & II & III & I & II & III & I & II & III \\
\hline Eriophorum angustifolium & 6 & 6 & 7 & 6 & 6 & 6 & & & & & & & & & & & & \\
\hline Marchantia polymorpha & 3 & 2 & 2 & & & & & & 2 & & & & & & & & & \\
\hline Dicranella cerviculata & 3 & 2 & 2 & 3 & 4 & 4 & & 6 & 2 & & & & & & & & & \\
\hline Juncus cf. compressus & & 1 & & 3 & 2 & 2 & 2 & 2 & & 2 & 2 & 2 & & & & & & \\
\hline Utricularia intermedia & & & & & & & & & & & 2 & 2 & 7 & 6 & 7 & & & \\
\hline Chara spec. & & & & & & & & & & 2 & & 3 & & & & 1 & & \\
\hline green algae & & & & & & & & & & & & 4 & & & & 2 & & \\
\hline Phragmites australis & & & & & & & & & & & 1 & & 7 & 8 & 6 & 8 & 8 & 8 \\
\hline Dicranella heteromalla & & & & & & & & & & & & & 2 & 2 & 2 & & & \\
\hline Carex rostrata & 2 & 2 & 3 & 2 & 2 & 2 & 7 & 7 & 6 & 7 & 6 & 6 & 3 & 3 & 3 & 3 & 3 & 3 \\
\hline Equisetum fluviatile & 2 & & & 2 & 2 & & 2 & 2 & 2 & 2 & 2 & 2 & 1 & 1 & 1 & 1 & & 1 \\
\hline Salix cinerea & 1 & 1 & & 1 & & & 1 & 1 & 1 & 1 & & & 1 & & 4 & 1 & & \\
\hline \multirow[t]{3}{*}{ Drepanocladus aduncus } & & & 2 & & & & & & & & & & 5 & & & 2 & & 4 \\
\hline & \multicolumn{6}{|c|}{ GK Carex-Lysimachia } & \multicolumn{6}{|c|}{ GK Typha-Hydrocharis } & \multicolumn{6}{|c|}{ GK Phragmites-Lemna } \\
\hline & \multicolumn{3}{|c|}{2010} & \multicolumn{3}{|c|}{2012} & \multicolumn{3}{|c|}{2010} & \multicolumn{3}{|c|}{2012} & \multicolumn{3}{|c|}{2010} & \multicolumn{3}{|c|}{2012} \\
\hline Species & I & II & III & I & II & III & I & II & III & I & II & III & I & II & III & I & II & III \\
\hline Thelypteris palustris & 4 & & & & & 6 & & & & & & & & & & & & \\
\hline Calamagrostis neglecta & 4 & & & & & 2 & & & & & & & & & & & & \\
\hline Carex elata & 2 & 5 & 6 & 8 & 5 & 2 & & & 7 & & & 8 & & & & & & \\
\hline Carex vesicaria & 7 & 2 & & 3 & 6 & 2 & 2 & 3 & & 5 & 5 & & & & & & & \\
\hline Typha latifolia & 6 & 7 & 6 & & 4 & 4 & 6 & 7 & 3 & 6 & 3 & 4 & & & & & & \\
\hline Galium palustre & 2 & 2 & 2 & 2 & 2 & 2 & & & & 2 & 2 & 2 & & & & & & \\
\hline Cardamine amara & 2 & 2 & 1 & 2 & 2 & & & & 1 & 2 & 1 & 2 & & & & & & \\
\hline Lycopus europeus & & 2 & & 2 & 2 & 2 & & & 1 & & 1 & 1 & & & & & & \\
\hline Lysimachia thyrsiflora & 1 & 2 & 2 & 3 & 2 & 2 & & & & 2 & 4 & 2 & & & & & & \\
\hline Lemna trisulca & & & & & & & 2 & & & & 2 & & & 1 & & 2 & 2 & 2 \\
\hline Phragmites australis & & & & & & & & & & & & & 7 & 7 & 8 & 9 & 7 & 8 \\
\hline Stratiotes aloides & & & & & & & & & & & & & 1 & 6 & & & 5 & 2 \\
\hline Drepanocladus aduncus & 2 & 5 & 2 & 6 & 8 & 3 & 3 & 2 & 2 & 8 & 3 & 7 & 2 & & & 2 & & 2 \\
\hline Hydrocharis morsus-ranae & & & & 2 & 3 & 2 & 3 & 3 & 2 & 4 & 6 & 3 & 3 & 5 & 4 & 5 & 8 & 6 \\
\hline Lemna minor & & & & & 2 & 2 & 2 & 1 & & 2 & 2 & 2 & 1 & 1 & & 2 & & \\
\hline
\end{tabular}

Vegetation types of sites studied in Barcianicha: Eriophorum angustifolium-Carex rostrata-reed (BA Eriophorum-Carex), Carex rostrata-Equisetum fluviatile-reed (BA Carex-Equisetum), Phragmites australis-Carex rostrata-reed (BA Phragmites-Carex), and Giel'čykaŭ Kašyl': Carex elata-Lysimachia thyrsiflora-reed (GK Carex-Lysimachia), Typha latifolia-Hydrocharis morsus-ranae-reed (GK Typha-Hydrocharis), Phragmites australis-Lemna trisulca-reed (GK Phragmites-Lemna). Plant cover scale according to Peet et al. (1998): Class $1=$ very few individuals, $2=$ cover of $0-1 \%, 3=1-2 \%, 4=2-5 \%, 5=5-10 \%, 6=10-25 \%, 7=25-50 \%, 8=50-75 \%, 9=75-95 \%, 10>=95 \%$. Species not exceeding cover class 2 are only shown if they meet class 2 in more than two relevés. 
Table A2. Mean $\pm \mathrm{SD}$ error of daytime $\left(\mathrm{PAR}>2 \mu \mathrm{mol} \mathrm{m} \mathrm{s}^{-2} \mathrm{~s}^{-1}\right) \mathrm{CH}_{4}$ flux rates, $\mathrm{PAR}, T_{\mathrm{in}}$, and $\mathrm{RH}_{\text {in }}$ by plot and chamber type $(\mathrm{DF}=\mathrm{opaque}$ mixed chamber, $\mathrm{TF}=$ transparent mixed chamber, $\mathrm{D}=$ not mixed opaque chamber). Values with same letter superscript do not differ significantly at $P<0.05$ (Mann-Whitney or Kruskal-Wallis test; post-hoc non-parametric Nemenyi test), data of BA Phragmites-Carex II and GK Phragmites-Lemna II from Minke et al. (2014).

\begin{tabular}{|c|c|c|c|c|c|c|c|c|c|}
\hline $\begin{array}{l}\text { Site, plot, } \\
\text { and date }\end{array}$ & $\begin{array}{l}\text { Chamber } \\
\text { type }\end{array}$ & $N$ & $\begin{array}{l}\text { PAR } \\
\left(\mu \mathrm{mol} \mathrm{m}{ }^{-2} \mathrm{~s}^{-1}\right)\end{array}$ & $\begin{array}{l}T_{\text {in }} \\
\left({ }^{\circ} \mathrm{C}\right)\end{array}$ & $\begin{array}{l}\mathrm{d} T_{\text {in }} \\
\left({ }^{\circ} \mathrm{C}\right)\end{array}$ & $\begin{array}{l}\mathrm{RH}_{\mathrm{in}} \\
(\%)\end{array}$ & $\begin{array}{l}\mathrm{dRH}_{\mathrm{in}} \\
(\%)\end{array}$ & $\begin{array}{l}\mathrm{CH}_{4} \text { flux } \\
\left(\mathrm{mg} \mathrm{CH}_{4}-\mathrm{C} \mathrm{m}^{-2} \mathrm{~h}^{-1}\right)\end{array}$ & $\begin{array}{l}\text { Methane } \\
\text { factor }\end{array}$ \\
\hline BA Eriophorum-Carex I & DF & 8 & $685^{a} \pm 208$ & $16.6^{\mathrm{a}} \pm 1.1$ & $1.0^{\mathrm{a}} \pm 0.2$ & $90.2^{\mathrm{a}} \pm 2.6$ & $7.5^{\mathrm{a}} \pm 1.7$ & $2.30^{\mathrm{a}} \pm 0.10$ & $\mathrm{TF} / \mathrm{DF}=1.09$ \\
\hline $2012-07-18$ & $\mathrm{TF}$ & 7 & $1145^{\mathrm{a}} \pm 224$ & $17.1^{\mathrm{a}} \pm 1.5$ & $3.0^{\mathrm{b}} \pm 0.5$ & $78.6^{\mathrm{a}} \pm 4.1$ & $3.8^{\mathrm{a}} \pm 0.8$ & $2.49^{\mathrm{a}} \pm 0.05$ & \\
\hline BA Carex-Equisetum III & DF & 7 & $937^{\mathrm{a}} \pm 401$ & $17.4^{\mathrm{a}} \pm 1.4$ & $1.5^{\mathrm{a}} \pm 0.4$ & $90.1^{\mathrm{a}} \pm 2.1$ & $5.8^{\mathrm{a}} \pm 1.7$ & $2.30^{\mathrm{a}} \pm 0.08$ & $\mathrm{TF} / \mathrm{DF}=0.99$ \\
\hline $2012-07-18$ & $\mathrm{TF}$ & 6 & $851^{\mathrm{a}} \pm 164$ & $17.8^{\mathrm{a}} \pm 1.5$ & $1.5^{\mathrm{a}} \pm 0.3$ & $80.2^{\mathrm{b}} \pm 3.0$ & $4.2^{\mathrm{a}} \pm 1.3$ & $2.28^{\mathrm{a}} \pm 0.08$ & \\
\hline BA Carex-Equisetum III & $\mathrm{D}$ & 14 & $482^{\mathrm{a}} \pm 85$ & $15.4^{\mathrm{a}} \pm 0.7$ & $0.7^{\mathrm{ab}} \pm 0.1$ & $79.4^{\mathrm{ab}} \pm 2.6$ & $9.1^{\mathrm{a}} \pm 1.0$ & $0.76^{\mathrm{a}} \pm 0.03$ & $\mathrm{TF} / \mathrm{D}=1.07$ \\
\hline \multirow[t]{2}{*}{$2012-09-16$} & DF & 14 & $535^{\mathrm{a}} \pm 95$ & $15.6^{\mathrm{a}} \pm 0.7$ & $0.5^{\mathrm{a}} \pm 0.1$ & $86.2^{\mathrm{a}} \pm 1.5$ & $7.5^{\mathrm{ab}} \pm 0.8$ & $0.80^{\mathrm{a}} \pm 0.04$ & $\mathrm{TF} / \mathrm{DF}=1.02$ \\
\hline & $\mathrm{TF}$ & 13 & $584^{\mathrm{a}} \pm 95$ & $15.3^{\mathrm{a}} \pm 0.6$ & $1.3^{\mathrm{b}} \pm 0.2$ & $75.4^{\mathrm{b}} \pm 2.3$ & $4.4^{\mathrm{b}} \pm 0.6$ & $0.81^{\mathrm{a}} \pm 0.02$ & \\
\hline GK Typha-Hydrocharis I & DF & 9 & $869^{\mathrm{a}} \pm 157$ & $24.3^{\mathrm{a}} \pm 1.2$ & $1.0^{\mathrm{a}} \pm 0.2$ & $94.4^{\mathrm{a}} \pm 1.7$ & $18.1^{\mathrm{a}} \pm 3.7$ & $16.61^{\mathrm{a}} \pm 0.43$ & $\mathrm{TF} / \mathrm{DF}=1.18$ \\
\hline $2012-07-12$ & $\mathrm{TF}$ & 9 & $868^{a} \pm 149$ & $24.9^{\mathrm{a}} \pm 0.9$ & $1.4^{\mathrm{a}} \pm 0.3$ & $88.6^{\mathrm{a}} \pm 2.7$ & $14.8^{\mathrm{a}} \pm 2.3$ & $19.52^{\mathrm{b}} \pm 1.20$ & \\
\hline GK Typha-Hydrocharis I & DF & 11 & $821^{\mathrm{a}} \pm 136$ & $19.9^{\mathrm{a}} \pm 1.2$ & $0.8^{\mathrm{a}} \pm 0.2$ & $85.3^{\mathrm{a}} \pm 3.0$ & $15.5^{\mathrm{a}} \pm 2.8$ & $14.04^{\mathrm{a}} \pm 0.24$ & $\mathrm{TF} / \mathrm{DF}=1.20$ \\
\hline $2012-07-13$ & $\mathrm{TF}$ & 10 & $1097^{\mathrm{a}} \pm 146$ & $20.7^{\mathrm{a}} \pm 1.4$ & $1.7^{\mathrm{b}} \pm 0.3$ & $80.3^{\mathrm{a}} \pm 3.7$ & $11.8^{\mathrm{a}} \pm 2.1$ & $18.00^{\mathrm{b}} \pm 0.20$ & \\
\hline GK Carex-Lysimachia I & DF & 9 & $923^{\mathrm{a}} \pm 115$ & $24.2^{\mathrm{a}} \pm 1.1$ & $1.0^{\mathrm{a}} \pm 0.2$ & $84.9^{\mathrm{a}} \pm 3.0$ & $9.2^{\mathrm{a}} \pm 1.5$ & $14.28^{\mathrm{a}} \pm 0.22$ & $\mathrm{TF} / \mathrm{DF}=1.10$ \\
\hline $2012-07-12$ & $\mathrm{TF}$ & 9 & $749^{\mathrm{a}} \pm 111$ & $24.8^{\mathrm{a}} \pm 1.1$ & $1.5^{\mathrm{a}} \pm 0.3$ & $82.3^{\mathrm{a}} \pm 2.9$ & $7.0^{\mathrm{a}} \pm 1.4$ & $15.76^{\mathrm{b}} \pm 0.38$ & \\
\hline GK Carex-Lysimachia I & DF & 11 & $1207^{\mathrm{a}} \pm 188$ & $20.1^{\mathrm{a}} \pm 1.3$ & $1.4^{\mathrm{a}} \pm 0.2$ & $83.4^{\mathrm{a}} \pm 3.3$ & $12.7^{\mathrm{a}} \pm 2.1$ & $14.62^{\mathrm{a}} \pm 0.33$ & $\mathrm{TF} / \mathrm{DF}=1.08$ \\
\hline $2012-07-13$ & $\mathrm{TF}$ & 10 & $1121^{\mathrm{a}} \pm 177$ & $21.1^{\mathrm{a}} \pm 1.5$ & $3.0^{\mathrm{b}} \pm 0.5$ & $78.8^{\mathrm{a}} \pm 4.3$ & $7.5^{\mathrm{a}} \pm 1.2$ & $15.81^{\mathrm{b}} \pm 0.23$ & \\
\hline BA Phragmites-Carex II & $\mathrm{D}$ & 16 & $830^{\mathrm{a}} \pm 130$ & $19.4^{\mathrm{a}} \pm 1.1$ & $0.6^{\mathrm{a}} \pm 0.2$ & $81.0^{\mathrm{a}} \pm 3.2$ & $11.8^{\mathrm{ab}} \pm 1.8$ & $9.86^{\mathrm{a}} \pm 1.40$ & $\mathrm{TF} / \mathrm{D}=1.01$ \\
\hline \multirow[t]{2}{*}{$2012-08-08$} & DF & 16 & $857^{\mathrm{a}} \pm 133$ & $19.7^{\mathrm{a}} \pm 1.1$ & $0.9^{\mathrm{a}} \pm 0.2$ & $81.9^{\mathrm{a}} \pm 3.3$ & $13.4^{\mathrm{a}} \pm 2.2$ & $10.17^{\mathrm{a}} \pm 1.50$ & $\mathrm{TF} / \mathrm{DF}=0.98$ \\
\hline & $\mathrm{TF}$ & 16 & $735^{\mathrm{a}} \pm 121$ & $19.2^{\mathrm{a}} \pm 1.2$ & $0.8^{\mathrm{a}} \pm 0.1$ & $76.5^{\mathrm{a}} \pm 3.7$ & $6.0^{\mathrm{b}} \pm 1.0$ & $9.95^{\mathrm{a}} \pm 1.51$ & \\
\hline GK Phragmites-Lemna II & $\mathrm{D}$ & 14 & $707^{\mathrm{a}} \pm 130$ & $20.6^{\mathrm{a}} \pm 1.2$ & $0.7^{\mathrm{ab}} \pm 0.2$ & $70.4^{\mathrm{a}} \pm 3.2$ & $6.0^{\mathrm{a}} \pm 1.5$ & $13.70^{\mathrm{a}} \pm 1.68$ & $\mathrm{TF} / \mathrm{D}=1.27$ \\
\hline \multirow[t]{2}{*}{$2011-09-21$} & DF & 13 & $819^{\mathrm{a}} \pm 125$ & $21.7^{\mathrm{a}} \pm 1.3$ & $1.0^{\mathrm{a}} \pm 0.2$ & $71.1^{\mathrm{a}} \pm 3.1$ & $13.8^{\mathrm{b}} \pm 1.8$ & $17.42^{\mathrm{a}} \pm 2.39$ & $\mathrm{TF} / \mathrm{DF}=1.00$ \\
\hline & $\mathrm{TF}$ & 12 & $893^{a} \pm 125$ & $23.1^{\mathrm{a}} \pm 1.0$ & $1.8^{\mathrm{b}} \pm 0.2$ & $66.5^{\mathrm{a}} \pm 2.5$ & $6.6^{\mathrm{a}} \pm 1.0$ & $17.46^{\mathrm{a}} \pm 2.08$ & \\
\hline
\end{tabular}


Table A3. Annual fluxes of $\mathrm{CO}_{2}, \mathrm{CH}_{4}$, and $\mathrm{N}_{2} \mathrm{O}$ with confidence intervals

\begin{tabular}{|c|c|c|c|c|c|c|c|}
\hline Site & Year & Plot & $\begin{array}{l}R_{\mathrm{eco}} \\
\left(\mathrm{g} \mathrm{CO}_{2}-\mathrm{Cm}^{-2} \mathrm{yr}^{-1}\right)\end{array}$ & $\begin{array}{l}\mathrm{GPP} \\
\left(\mathrm{g} \mathrm{CO}_{2}-\mathrm{C} \mathrm{m}^{-2} \mathrm{yr}^{-1}\right)\end{array}$ & $\begin{array}{l}\mathrm{NEE} \\
\left(\mathrm{gCO}_{2}-\mathrm{Cm}^{-2} \mathrm{yr}^{-1}\right)\end{array}$ & $\begin{array}{l}\mathrm{CH}_{4} \text { emissions } \\
\left(\mathrm{g} \mathrm{CH}_{4}-\mathrm{C} \mathrm{m}^{-2} \mathrm{yr}^{-1}\right)\end{array}$ & $\begin{array}{l}\mathrm{N}_{2} \mathrm{O} \text { emissions } \\
\left(\mathrm{mg} \mathrm{N}_{2} \mathrm{O}-\mathrm{N} \mathrm{m}^{-2} \mathrm{yr}^{-1}\right)\end{array}$ \\
\hline BA & 1 th & I & 378 (359 to 398$)$ & $-496(-514$ to -478$)$ & $-118(-132$ to -104$)$ & 11 (9 to 14$)$ & $-80(-189$ to 21$)$ \\
\hline \multirow[t]{5}{*}{ Eriophorum-Carex } & & II & 358 (338 to 378$)$ & $-441(-449$ to -433$)$ & $-83(-102$ to -63$)$ & $10(8$ to 12$)$ & $-89(-213$ to 49$)$ \\
\hline & & III & 355 (338 to 372$)$ & $-411(-415$ to -406$)$ & $-56(-75$ to -37$)$ & $10(8$ to 13$)$ & $79(-65$ to 245$)$ \\
\hline & 2nd & I & 436 (413 to 459$)$ & $-444(-451$ to -437$)$ & $-8(-35$ to 19$)$ & $12(10$ to 14$)$ & $32(-67$ to 130$)$ \\
\hline & & II & 391 (367 to 414$)$ & $-413(-421$ to -406$)$ & $-23(-51$ to 6$)$ & 11 (9 to 12$)$ & $39(-38$ to 115$)$ \\
\hline & & III & $390(379$ to 401$)$ & $-381(-387$ to -375$)$ & $9(-5$ to 23$)$ & $11(10$ to 14$)$ & $95(-75$ to 284$)$ \\
\hline BA & 1 th & I & 210 (195 to 226$)$ & $-287(-296$ to -278$)$ & $-77(-87$ to -66$)$ & 15 (13 to 18$)$ & $-40(-148$ to 71$)$ \\
\hline \multirow[t]{5}{*}{ Carex-Equisetum } & & II & 245 (227 to 263$)$ & $-350(-362$ to -338$)$ & $-105(-115$ to -95$)$ & $19(16$ to 23$)$ & $-21(-132$ to 85$)$ \\
\hline & & III & 241 (226 to 255$)$ & $-322(-334$ to -310$)$ & $-82(-88$ to -76$)$ & $17(14$ to 21$)$ & $-23(-203$ to 168$)$ \\
\hline & 2nd & I & 303 (280 to 326$)$ & $-286(-292$ to -280$)$ & $17(-9$ to 43$)$ & $10(8$ to 13$)$ & $-28(-110$ to 56$)$ \\
\hline & & II & 353 (334 to 372 ) & $-331(-335$ to -327$)$ & $22(2$ to 43$)$ & $14(13$ to 19$)$ & $-84(-150$ to -12$)$ \\
\hline & & III & 323 (300 to 347 ) & $-290(-295$ to -284$)$ & $34(10$ to 57$)$ & 14 (12 to 16$)$ & $-113(-296$ to 79$)$ \\
\hline BA & 1 th & I & 498 (473 to 522$)$ & $-967(-999$ to -935$)$ & $-469(-517$ to -421$)$ & $32(26$ to 39$)$ & $-515(-833$ to -226$)$ \\
\hline \multirow[t]{5}{*}{ Phragmites-Carex } & & II & $693(646$ to 741$)$ & $-1555(-1600$ to -1509$)$ & $-861(-942$ to -780$)$ & 46 (34 to 57$)$ & $356(-246$ to -982$)$ \\
\hline & & III & $650(594$ to 705$)$ & $-902(-921$ to -884$)$ & $-253(-318$ to -188$)$ & 48 (36 to 61$)$ & $-75(-487$ to 335$)$ \\
\hline & 2nd & I & 615 (562 to 669$)$ & $-963(-980$ to -947$)$ & $-348(-410$ to -285$)$ & $30(21$ to 35$)$ & $-63(-977$ to 849$)$ \\
\hline & & II & $769(691$ to 848$)$ & $-1122(-1136$ to -1108$)$ & $-353(-437$ to -269$)$ & 45 (36 to 57 ) & $-466(-943$ to 849$)$ \\
\hline & & III & $732(680$ to 785$)$ & $-1018(-1052$ to -984$)$ & $-286(-360$ to -212$)$ & $32(24$ to 42$)$ & $87(-174$ to 374$)$ \\
\hline GK & 1 th & I & 877 (836 to 918$)$ & $-801(-813$ to -790$)$ & $76(36$ to 116$)$ & $59(49$ to 73$)$ & $95(-673$ to 886$)$ \\
\hline \multirow[t]{5}{*}{ Typha-Hydrocharis } & & II & $923(912$ to 934$)$ & $-831(-844$ to -817$)$ & $92(74$ to 111$)$ & $59(47$ to 73$)$ & $130(-279$ to 533$)$ \\
\hline & & III & $963(942$ to 984$)$ & $-680(-697$ to -663$)$ & 284 (263 to 304$)$ & 61 (44 to 83$)$ & $220(-52$ to 515$)$ \\
\hline & 2nd & I & 1104 (1046 to 1161$)$ & $-1446(-1480$ to -1412$)$ & $-342(-424$ to -261$)$ & $63(51$ to 75$)$ & $151(-124$ to 449$)$ \\
\hline & & II & $827(816$ to 838$)$ & $-870(-881$ to -859$)$ & $-43(-60$ to -27$)$ & 65 (50 to 82$)$ & $74(-223$ to 372$)$ \\
\hline & & III & $988(972$ to 1005$)$ & $-943(-967$ to -919$)$ & $46(20$ to 72$)$ & 77 (59 to 103$)$ & $76(-111$ to 257$)$ \\
\hline GK & 1 th & I & 1124 (1090 to 1158$)$ & $-962(-989$ to -934$)$ & $162(135$ to 189$)$ & $86(74$ to 100$)$ & $-137(-677$ to 419$)$ \\
\hline \multirow[t]{5}{*}{ Carex-Lysimachia } & & II & $1167(1124$ to 1211$)$ & $-1065(-1084$ to -1047$)$ & $102(60$ to 144$)$ & $72(59$ to 86$)$ & $162(-160$ to 505$)$ \\
\hline & & III & 1024 (1005 to 1044$)$ & $-792(-814$ to -770$)$ & 233 (206 to 259 ) & $101(75$ to 140$)$ & $-91(-358$ to 160$)$ \\
\hline & 2nd & I & $1246(1224$ to 1268$)$ & $-811(-837$ to -785$)$ & 435 (395 to 475$)$ & $84(65$ to 121$)$ & $100(-140$ to 346$)$ \\
\hline & & II & 1331 (1296 to 1367$)$ & $-1205(-1248$ to -1162$)$ & $126(56$ to 196$)$ & $67(56$ to 82$)$ & $-56(-220$ to 88$)$ \\
\hline & & III & 1233 (1219 to 1246$)$ & $-1146(-1188$ to -1104$)$ & 87 (42 to 132$)$ & $102(76$ to 162$)$ & $229(-128$ to 599$)$ \\
\hline GK & 1 th & I & $921(892$ to 949$)$ & $-1446(-1511$ to -1380$)$ & $-525(-607$ to -443$)$ & $113(88$ to 139$)$ & $58(-524$ to 684$)$ \\
\hline \multirow[t]{5}{*}{ Phragmites-Lemna } & & II & 767 (729 to 804$)$ & $-1516(-1568$ to -1465$)$ & $-750(-827$ to -673$)$ & $61(43$ to 83$)$ & $-101(-783$ to 548$)$ \\
\hline & & III & 1121 (1037 to 1206$)$ & $-1680(-1737$ to -1623$)$ & $-559(-623$ to -495$)$ & $112(73$ to 164$)$ & $468(-256$ to 1176$)$ \\
\hline & 2nd & I & 1170 (1122 to 1219$)$ & $-2678(-2745$ to -2611$)$ & $-1507(-1584$ to -1431$)$ & $87(65$ to 113$)$ & $99(-652$ to 872$)$ \\
\hline & & II & $970(929$ to 1012$)$ & $-2235(-2362$ to -2108$)$ & $-1265(-1381$ to -1149$)$ & 77 (57 to 110$)$ & $-437(-1017$ to 140$)$ \\
\hline & & III & 1135 (1062 to 1208$)$ & $-1887(-1939$ to -1836$)$ & $-752(-825$ to -679$)$ & 139 (86 to 202$)$ & $330(-253$ to 937$)$ \\
\hline
\end{tabular}

Uncertainties of $\mathrm{CO}_{2}$ balances on the plot level were calculated as $50 \%$ of the difference between the $\mathrm{H}$ approach and the $\mathrm{LS}$ approach plus the $90 \% \mathrm{CI}^{\prime}$ of the $\mathrm{H}$ approach. Plot level uncertainties for $\mathrm{CH}_{4}$ represent the $90 \%$ confidence intervals (CI's) of the models, but for $\mathrm{N}_{2} \mathrm{O}$ only the $90 \%$ CI's of the measured $\mathrm{N}_{2} \mathrm{O}$ fluxes. 
Acknowledgements. This study was funded by the KfW Entwicklungsbank in the framework of the International Climate Initiative of the German Federal Ministry for the Environment, Nature Conservation and Nuclear Safety (BMU) under BMU project Reference No.: II. C. 53, and by the Centre for International Migration and Development (CIM) and the Royal Society for the Protection of Birds (RSPB). We thank APB - BirdLife Belarus and the National Academy of Sciences of Belarus for creating ideal research conditions, Hans Joosten for support in designing the study and for commenting the manuscript, Nadzeya Liashchynskaya, Hanna Grabenberger, Aleksandr Novik, Nikolaj Belovezhkin, Konstantin Timokhov and Aleksandr Pavlyuchenko for help in the field, Sergej Zui for construction and maintenance of measuring equipment, Vyacheslav Rakovich for showing us Barcianicha, Petr Boldovskij, Vadim Protasevich and the students and teachers of the school of Z'dzitava for warm welcome, logistical support and information on land use history, Michel Bechthold for advice on evaluation of the hydrological data, Roland Fuß, Katharina Leiber-Sauheitl, and Thomas Leppelt for consultations on statistical issues, and two anonymous referees for constructive remarks on the manuscript.

Edited by: P. Stoy

\section{References}

Abramov, I. I. and Volkova, L. A.: Handbook of Mosses of Karelia, KMK Scientific Press Delphos, Moscow, 1998.

AG Boden: Bodenkundliche Kartieranleitung (Soil survey manual), 5th Edn., Hannover, 2005.

Alm, J., Talanov, A., Saarnio, S., Silvola, J., Ikkonen, E., Aaltonen, H., Nykänen, H., and Martikainen, P. J.: Reconstruction of the carbon balance for microsites in a boreal oligotrophic pine fen, Finland, Oecologia, 110, 423-431, 1997.

Armstrong, J. and Armstrong, W.: A convective through-flow of gases in Phragmites australis (Cav.) Trin. Ex Steud., Aquat. Bot., 39, 75-88, 1991.

Armstrong, J., Armstrong, W., Beckett, P. M., Halder, J. E., Lythe, S., Holt, R., and Sinclair, A.: Pathways of aeration and the mechanisms and beneficial effects of humidity and Venturi induced convections in Phragmites australis (Cav.) Trin. Ex Steud., Aquat. Bot., 54, 177-198, 10, 1996.

Armstrong, W.: Aeration in higher plants, Adv. Bot. Res., 7, 236332, 1979.

Asaeda, T., Manatunge, J., Roberts, J., and Hai, D. N.: Seasonal dynamics of resource translocation between the aboveground organs and age-specific rhizome segments of Phragmites australis, Environ. Exp. Bot., 57, 9-18, 2006.

Bellisario, L. M., Bubier, J. L., Moore, T. R., and Chanton, J. P.: Controls on $\mathrm{CH}_{4}$ emissions from a northern peatland, Global Biogeochem. Cy., 13, 81-91, 1999.

Beyer, C. and Höper, H.: Greenhouse gas exchange of rewetted bog peat extraction sites and a Sphagnum cultivation site in northwest Germany, Biogeosciences, 12, 2101-2117, doi:10.5194/bg12-2101-2015, 2015.

Blain, D., Murdiyarso, D., Couwenberg, J., Nagata, O., RenouWilson, F., Sirin, A., Strack, M., Tuittila, E.-S., Wilson, D., Evans, C. D., Fukuda, M., and Parish, F.: Chapter 3: Rewetted organic soils, in: 2013 Supplement to the 2006 IPCC Guidelines for National Greenhouse Gas Inventories: Wetlands, edited by: Hiraishi, T., Krug, T., Tanabe, K., Srivastava, N., Baasansuren, J., Fukuda, M., and Troxler, T. G., IPCC, Switzerland, 3.1-3.42, 2014.

Brix, H., Sorrell, B. K., and Orr, P. T.: Internal pressurization and convective gas flow in some emergent freshwater macrophytes, Limnol. Oceanogr., 37, 1420-1433, 1992.

Brix, H., Sorrell, B. K., and Lorenzen, B.: Are Phragmitesdominated wetlands a net source or net sink of greenhouse gases?, Aquat. Bot., 69, 313-324, 2001.

Chanton, J. P. and Whiting, G. J.: Trace gas exchange in freshwater and coastal marine environments: ebullition and transport by plants, in: Biogenic Trace Gases: Measuring Emissions from Soil and Water, edited by: Matson, P. A. and Harriss, R. C., Blackwell Science Ltd., Oxford, UK, 98-125, 1995.

Chanton, J. P., Whiting, G., Happell, J., and Gerard, G.: Contrasting rates and diurnal patterns of methane emission from different types of vegetation, Aquat. Bot., 46, 111-128, 1993.

Chanton, J. P., Bauer, J. E., Glaser, P. A., Siegel, D. I., Kelley, C. A., Tyler, S. C., Romanowicz, E. H., and Lazrus, A.: Radiocarbon evidence for the substrates supporting methane formation within northern Minnesota peatlands, Geochim. Cosmochim. Ac., 59, 3663-3668, 1995.

Chapin III, F. S., Matson, P. A., and Mooney, H. A.: Principles of Terrestrial Ecosystem Ecology, Springer-Verlag, New York, 2002.

Chu, H., Gottgens, J. F., Chen, J., Sun, G., Desai, A. R., Ouyang, Z., Shao, C., and Czajkowski, K.: Climatic variability, hydrologic anomaly, and methane emission can turn productive freshwater marshes into net carbon sources, Glob. Change Biol., 21, 11651181, doi:10.1111/gcb.12760, 2015.

Conrad, R., Schütz, H., and Babbel, M.: Temperature limitation of hydrogen turnover and methanogenesis in anoxic paddy soil, FEMS Microbiol. Ecol., 45, 281-289, 1987.

Couwenberg, J., Augustin, J., Michaelis, D., and Joosten, H.: Emission Reductions from Rewetting of Peatlands, Towards a Field Guide for the Assessment of Greenhouse Gas Emissions from Central European Peatlands, Duene/RSPB, Greifswald/Sandy, 2008.

Couwenberg, J., Thiele, A., Tanneberger, F., Augustin, J., Bärisch, S., Dubovik, D., Liashchynskaya, N., Michaelis, D., Minke, M., Skuratovich, A., and Joosten, H.: Assessing greenhouse gas emissions from peatlands using vegetation as a proxy, Hydrobiologia, 674, 67-89, doi:10.1007/s10750-011-0729-x, 2011.

Daulat, W. E. and Clymo, R. S.: Effects of temperature and watertable on the efflux of methane from peatland surface cores, Atmos. Environ., 32, 3207-3218, 1998.

Dise, N. B., Gorham, E., and Verry, E. S.: Environmental factors controlling methane emissions from peatlands in Northern Minnesota, J. Geophys. Res., 98, 10583-10594, 1993.

Drösler, M.: Trace Gas Exchange and Climatic Relevance of Bog Ecosystems, southern Germany, PhD thesis, Technische Universität München, München, 2005.

Drösler, M., Freibauer, A., Christensen, T. R., and Friborg, T.: Observations and status of peatland greenhouse gas emissions in Europe, in: The Continental-Scale Greenhouse Gas Balance of Europe, edited by: Dolman, H., Valentini, R., and Freibauer, A., Ecol. Stud., 203, 243-261, 2008. 
Drösler, M., Verchot, L. V., Freibauer, A., Pan, G., Evans, C. D., Bourbonniere, R. A., Alm, J. P., Page, S., Agus, F., Hergoualc'h, K., Couwenberg, J., Jauhiainen, J., Sabiham, S., Wang, C., Srivastava, N., Borgeau-Chavez, L., Hooijer, A., Minkkinen, K., French, N., Strand, T., Sirin, A., Mickler, R., Tansey, K., and Larkin, N.: Chapter 2: Drained inland organic soils, in: 2013 Supplement to the 2006 IPCC Guidelines for National Greenhouse Gas Inventories: Wetlands, edited by: Hiraishi, T., Krug, T., Tanabe, K., Srivastava, N., Baasansuren, J., Fukuda, M., and Troxler, T. G., IPCC, Switzerland, 2.1-2.76, 2014.

Dušek, J., Žížková, H., Stellner, S., Czerný, R., and Květ, J.: Fluctuating water table affects gross ecosystem production and gross radiation use efficiency in a sedge-grass marsh, Hydrobiologia, 692, 57-66, doi:10.1007/s10750-012-0998-z, 2012.

Eickenscheidt, T., Heinichen, J., and Drösler, M.: The greenhouse gas balance of a drained fen peatland is mainly controlled by land-use rather than soil organic carbon content, Biogeosciences, 12, 5161-5184, doi:10.5194/bg-12-5161-2015, 2015.

Efron, B.: Bootstrap methods: Another look at the jackknife, Ann. Stat., 7, 1-26, 1979.

Falge, E., Baldocchi, D., Olson, R., Anthoni, P., Aubinet, M., Bernhofer, C., Burba, G., Ceulemans, R., Clement, R., Dolman, H., Granier, A., Gross, P., Grünwald, T., Hollinger, D., Jensen, N.O., Katul, G., Keronen, P., Kowalski, A., Lai, C. T., Law, B. E., Meyers, T., Moncrieff, J., Moors, E., Munger, J. W., Pilegaard, K., Rannik, Ü., Rebmann, C., Suyker, A., Tenhunen, J., Tu, K., Verma, S., Vesala, T., Wilson, K., and Wofsy, S.: Gap filling strategies or defensible annual sums of net ecosystem exchange, Agr. Forest Meteorol., 107, 43-69, 2001.

Gilmanov, T. G., Soussana, J. F., Aires, L., Allard, V., Ammann, C., Balzarolo, M., Barcza, Z., Bernhofer, C., Campbell, C. L., Cernusca, A., Cescatti, A., Clifton-Brown, J., Dirks, B. O. M., Dore, S., Eugster, W., Fuhrer, J., Gimeno, C., Gruenwald, T., Haszpra, L., Hensen, A., Ibrom, A., Jacobs, A. F. G., Jones, M. B., Lanigan, G., Laurila, T., Lohila, A., Manca, G., Marcolla, B., Nagy, Z., Pilegaard, K., Pinter, K., Pio, C., Raschi, A., Rogiers, N., Sanz, M. J., Stefani, P., Sutton, M., Tuba, Z., Valentini, R., Williams, M. L., and Wohlfahrt, G.: Partitioning European grassland net ecosystem $\mathrm{CO}_{2}$ exchange into gross primary productivity and ecosystem respiration using light response function analysis, Agr. Ecosyst. Environ., 121, 93-120, 2007.

Günther, A., Jurasinski, G., Huth, V., and Glatzel, S.: Opaque closed chambers underestimate methane fluxes of Phragmites australis (Cav.) Trin. ex Steud., Environ. Monit. Assess., 186, 2151-2158, doi:10.1007/s10661-013-3524-5, 2013.

Günther, A., Huth, V., Jurasinski, G., and Glatzel, S.: The effect of biomass harvesting on greenhouse gas emissions from a rewetted temperate fen, GCB Bioenergy, 7, 1092-1106, doi:10.1111/gcbb.12214, 2014.

Hahn-Schöfl, M., Zak, D., Minke, M., Gelbrecht, J., Augustin, J., and Freibauer, A.: Organic sediment formed during inundation of a degraded fen grassland emits large fluxes of $\mathrm{CH}_{4}$ and $\mathrm{CO}_{2}$, Biogeosciences, 8, 1539-1550, doi:10.5194/bg-8-15392011, 2011.

Hendriks, D. M. D., van Huissteden, J., Dolman, A. J., and van der Molen, M. K.: The full greenhouse gas balance of an abandoned peat meadow, Biogeosciences, 4, 411-424, doi:10.5194/bg-4411-2007, 2007.
Hirota, M., Tang, Y., Hu, Q., Hirata, S., Kato, T., Mo, W., Cao, G., and Mariko, S.: Methane emissions from different vegetation zones in a Qinghai-Tibetan Plateau wetland, Soil Biol. Biochem., 36, 737-748, 2004.

Hoffmann, M., Jurisch, N., Albiac, B. E., Hagemann, U., Drösler, M., Sommer, M., and Augustin, J.: Automated modeling of ecosystem $\mathrm{CO} 2$ fluxes based on periodic closed chamber measurements: a standardized conceptual and practical approach, Agr. Forest Meteorol., 200, 30-45, 2015.

Joabsson, A., Christensen, T. R., and Wallén, B.: Influence of vascular plant photosynthetic rate on $\mathrm{CH}_{4}$ emission from peat monoliths from southern boreal Sweden, Polar Res., 18, 215-220, 1999.

Joosten, H. and Clarke, D.: Wise Use of Mires and Peatlands Background and Principles Including a Framework for DecisionMaking, Saarijärvi, International Mire Conservation Group and International Peat Society, 2002.

Joosten, H., Tapio-Biström, M.-L., and Tol, S.: Peatlands - Guidance for Climate Change Mitigation by Conservation, Rehabilitation and Sustainable Use, FAO and Wetlands International, Rome, 2012.

Jurasinski, G., Koebsch, F., and Hagemann, U.: Flux: Flux Rate Calculation from Dynamic Closed Chamber Measurements, R Package Version 0.2-1, Rostock, 2012.

Juutinen, S., Alm, J., Larmola, T., Saarnio, S., Martikainen, P. J., and Silvola, J.: Stand-specific diurnal dynamics of $\mathrm{CH}_{4}$ fluxes in boreal lakes: patterns and controls, J. Geophys. Res., 109, D19313, doi:10.1029/2004JD004782, 2004.

Kadastrovyj spravochnik: Torfyanoj fond Belorusskoj SSR, Cadastral reference "Peat fond of the BSSR", Minsk, 1979.

Kankaala, P., Käki, T., and Ojala, A.: Quality of detritus impacts on spatial variation of methane emissions from littoral sediment of a boreal lake, Arch. Hydrobiol., 157, 47-66, 2003.

Kankaala, P., Ojala, A., and Käki, T.: Temporal and spatial variation in methane emissions from a flooded transgression shore of a boreal lake, Biogeochemistry, 68, 297-311, 2004.

Kettunen, A., Kaitala, V., Alm, J., Silvola, J., Nykänen, H., and Martikainen, P. J.: Predicting variations in methane emissions from boreal peatlands through regression models, Boreal Environ. Res., 5, 115-131, 2000.

Kim, J., Verma, S. B., and Billesbach, D. P.: Seasonal variation in methane emission from a temperate Phragmites-dominated marsh: effect of growth stage and plant mediated transport, Glob. Change Biol., 5, 433-440, 1998.

King, J. Y., Reeburgh, W. S., and Regli, S. K.: Methane emission and transport by arctic sedges in Alaska: results of a vegetation removal experiment, J. Geophys. Res., 103, 29083-29092, 1998.

Knox, S. H., Sturtevant, C., Matthes, J. H., Koteen, L., Verfaillie, J., and Baldocchi, D.: Agricultural peatland restoration: effects of land-use change on greenhouse gas $\left(\mathrm{CO}_{2}\right.$ and $\left.\mathrm{CH}_{4}\right)$ fluxes in the Sacramento-San Joaquin Delta, Glob. Change Biol., 21, 750 765, 2015.

Koebsch, F., Glatzel, S., Hofmann, J., Forbrich, I., and Jurasinski, $\mathrm{G} .: \mathrm{CO}_{2}$ exchange of a temperate fen during the conversion from moderately rewetting to flooding, J. Geophys. Res.-Biogeo., 118, 940-950, doi:10.1002/jgrg.20069, 2013.

Köppen, W.: Das geographische System der Klimate, in: Handbuch der Klimatologie, Vol. IC, edited by: Köppen, W. and Geiger, R., Borntraeger, Berlin, C1-C44, 1936. 
Koska, I., Succow, M., Clausnitzer, U., Timmermann, T., and Roth, S.: Vegetationskundliche Kennzeichnung von Mooren (topische Betrachtung), in: Landschaftsökologische Moorkunde, edited by: Succow, M. and Joosten, H., Schweizerbart, Stuttgart, 112$184,2001$.

Kottek, M., Grieser, J., Beck, C., Rudolf, B., and Rubel, F.: World map of the Köppen-Geiger climate classification up-dated, Meteorol. Z., 15, 259-263, 2006.

Kozulin, A., Tanovitskaya, N., and Vershitskaya, I.: Methodical Recommendations for Ecological Rehabilitation of Damaged Mires and Prevention of Disturbance to the Hydrological Regime of Mire Ecosystems in the Process of Drainage, Scientific and Practical Centre for Bio Resources, Institute for Nature Management of the National Academy of Sciences of Belarus, 2010.

Laine, A., Wilson, D., Kiely, G., and Byrne, K. A.: Methane flux dynamics in an Irish lowland blanket bog, Plant Soil, 299, 181193, doi:10.1007/s11104-007-9374-6, 2007.

Leiber-Sauheitl, K., Fuß, R., Voigt, C., and Freibauer, A.: High $\mathrm{CO}_{2}$ fluxes from grassland on histic Gleysol along soil carbon and drainage gradients, Biogeosciences, 11, 749-761, doi:10.5194/bg-11-749-2014, 2014.

Lloyd, J. and Taylor, J. A.: On the temperature dependence of soil respiration, Funct. Ecol., 8, 315-323, 1994.

Maksimenkov, M. V., Pugachevskij, A. V., and Rakovich, V. V.: Nauchnoe Obosnovanie povtornogo zabolachivaniya vyrabotannogo torfyanogo mestorozhdeniya "Bortenikha" (Scientific justification of rewetting of the cutaway peatland "Barcianicha"), The Forest Ministry of the Republic of Belarus, Minsk, 2006.

Michaelis, L. and Menten, M. L.: Die Kinetik der Invertinwirkung, Biochem. Z., 49, 333-369, 251913.

Minayeva, T., Sirin, A., and Bragg, O. (Eds.): A Quick Scan of Peatlands in Central and Eastern Europe, Wetlands International, Wageningen, 2009.

Minke, M., Augustin, J., Hagemann, U., and Joosten, H.: Similar methane fluxes measured by transparent and opaque chambers point at belowground connectivity of Phragmites australis beyond the chamber footprint, Aquat. Bot., 113, 63-71, 2014.

Moriasi, D. N., Arnold, J. G., Van Liew, M. W., Binger, R. L., Harmel, R. D., and Veith, T.: Model evaluation guidelines for systematic quantification of accuracy in water-shed simulations, T. ASABE, 50, 885-900, 2007.

Morrissey, L. A., Zobel, D. B., and Livingston, G. P.: Significance of stomatal control on methane release from Carex-dominated wetlands, Chemosphere, 26, 339-355, 1993.

Myhre, G., Shindell, D., Bréon, F.-M., Collins, W., Fuglestvedt, J., Huang, J., Koch, D., Lamarque, J.-F., Lee, D., Mendoza, B., Nakajima, T., Robock, A., Stephens, G., Takemura, T., and Zhang, H.: Anthropogenic and natural radiative forcing, in: Climate Change 2013: The Physical Science Basis, Contribution of Working Group I to the Fifth Assessment Report of the Intergovernmental Panel on Climate Change, edited by: Stocker, T. F., Qin, D., Plattner, G.-K., Tignor, M., Allen, S. K., Boschung, J., Nauels, A., Xia, Y., Bex, V., and Midgley, P. M., Cambridge University Press, Cambridge, UK, New York, NY, USA, 659-740, 2013.

Peet, R. K., Wentworth, T. R., and White, P. S.: A flexible, multipurpose method for recording vegetation composition and structure, Castanea, 63, 262-274, 1998.
Rinne, J., Riutta, T., Pihlatie, M., Aurela, M., Haapanala, S., Tuovinen, J.-P., and Tuittila, E.-S.: Annual cycle of methane emission from a boreal fen measured by the eddy covariance technique, Tellus B, 59, 449-457, 2007.

Rocha, A. V. and Goulden, M. L.: Large interannual $\mathrm{CO}_{2}$ and energy exchange variability in a freshwater marsh under consistent environmental conditions, J. Geophys. Res., 113, G04019, doi:10.1029/2008JG000712, 2008.

Rocha, A. V., Potts, D. L., and Goulden, M. L.: Standing litter as a driver of interannual $\mathrm{CO}_{2}$ exchange variability in a freshwater marsh, J. Geophys. Res., 113, G04020, doi:10.1029/2008JG000713, 2008.

Rothmaler, W.: Exkursionsflora von Deutschland: Kritischer Band (Flora of Germany), 9th Edn., Spektrum, Heidelberg, Berlin, 2002.

Saarnio, S., Alm, J., Silvola, J., Lohila, A., Nykänen, H., and Martikainen, P. J.: Seasonal variation in $\mathrm{CH}_{4}$ emissions and production and oxidation potentials at microsites on an oligotrophic pine fen, Oecologia, 110, 414-422, 1997.

Samaritani, E., Siegenthaler, A., Yli-Petäys, M., Buttler, A., Christin, P.-A., and Mitchell, E. A. D.: Seasonal net ecosystem carbon exchange of a regenerating cutaway bog: how long does it take to restore the C-sequestration function?, Restor. Ecol., 19, 480-489, doi:10.1111/j.1526-100X.2010.00662.x, 2011.

Scarton, F., Day, J. W., and Rismondo, A.: Above and belowground production of Phragmites australis in the Po Delta, Italy, Boll. Mus. civ. St. nat. Venezia, 49, 213-222, 1999.

Schierup, H. H.: Biomass and primary productivity in a Phragmites communis Trin. swamp in North Jutland, Denmark, Verh. Internat. Verein. Limnol., 20, 93-99, 1978.

Schütz, H., Seiler, W., and Conrad, R.: Influence of soil temperature on methane emission from rice paddy fields, Biogeochemistry, 11, 11-95, 1990.

Soetaert, K., Hoffmann, M., Meire, P., Starink, M., Van Oevelen, D., Van Regenmortel, S., and Cox, T.: Modeling growth and carbon allocation in two reed beds (Phragmites australis) in the Scheldt estuary, Aquat. Bot., 79, 211-234, 2004.

Soini, P., Riutta, T., Yli-Petäys, M., and Vasander, H.: Comparison of vegetation and $\mathrm{CO}_{2}$ dynamics between a restored cutaway peatland and a pristine fen: evaluation of the restoration success, Restor. Ecol., 18, 894-903, doi:10.1111/j.1526100X.2009.00520.x, 2010.

Strachan, I. B., Nugent, K. A., Crombie, S., and Bonneville, M.-C.: Carbon dioxide and methane exchange at a cool-temperate freshwater marsh, Environ. Res. Lett., 10, 065006, doi:10.1088/17489326/10/6/065006, 2015.

Strack, M. and Zuback, Y. C. A.: Annual carbon balance of a peatland $10 \mathrm{yr}$ following restoration, Biogeosciences, 10, 2885-2896, doi:10.5194/bg-10-2885-2013, 2013.

Tanneberger, F. and Wichtmann, W. (Eds.): Carbon Credits from Peatland Rewetting, Climate - Biodiversity - Land Use, Science, Policy, Implementation and Recommendations of a Pilot Project in Belarus, Schweizerbart, Stuttgart, 2011.

Tanovitskaya, N. and Kozulin, A.: Peatlands in Belarus, in: Carbon Credits from Peatland Rewetting, Climate - Biodiversity - Land Use, Science, Policy, Implementation and Recommendations of a Pilot Project in Belarus, edited by: Tanneberger, F. and Wichtmann, W., Schweizerbart, Stuttgart, 3-12, 2011. 
Thiele, A., Edom, F., and Liashchynskaya, N.: Prediction of vegetation development with and without rewetting, in: Carbon Credits from Peatland Rewetting, Climate - Biodiversity - Land Use, Science, Policy, Implementation and Recommendations of a Pilot Project in Belarus, edited by: Tanneberger, F. and Wichtmann, W., Schweizerbart, Stuttgart, 42-52, 2011.

Tuittila, E.-S., Komulainen, V.-M., Vasander, H., and Laine, J.: Restored cut-away peatland as a sink for atmospheric $\mathrm{CO}_{2}$, Oecologia, 120, 563-574, 1999.

Tuittila, E.-S., Komulainen, V.-M., Vasander, H., Nykänen, H., Martikainen, P. J., and Laine, J.: Methane dynamics of a restored cutaway peatland, Glob. Change Biol., 6, 569-581, 2000.

Van der Nat, F. J. and Middelburg, J. J.: Methane emission from tidal freshwater marshes, Biogeochemistry, 49, 103-121, 2000.

Vretare, V., Weisner, 5 S. E. B., Strand, J. A., and Granéli, W.: Phenotypic plasticity in Phragmites australis as a functional response to water depth, Aquat. Bot., 69, 127-145, 2001.

Waddington, J. M. and Day, S. M.: Methane emissions from a peatland following restoration, J. Geophys. Res., 112, G03018, doi:10.1029/2007JG000400, 2007.

Westlake, D. F.: The primary productivity of water plants, in: Studies on Aquatic Vascular Plants, edited by: Symoens, J. J., Hooper, S. S., and Compère, P., Royal Botanical Society of Belgium, Bruessls, 165-180, 1982.

Wetlands International: Restoring Peatlands in Russia - For Fire Prevention and Climate Change Mitigation (PEATRUS), Seventh Progress Report, submitted, KfW, 2015.

Whalen, S. C.: Biogeochemistry of methane exchange between natural wetlands and the atmosphere, Environ. Eng. Sci., 22, 73-94, 2005.

Whiting, G. J. and Chanton, J. P.: Plant-dependent $\mathrm{CH}_{4}$ emission in a subarctic Canadian fen, Global Biogeochem. Cy., 6, 225-231, 1992.

Whiting, G. J. and Chanton, J. P.: Primary production control of methane emission from wetlands, Nature, 367, 794-795, 1993.
Whiting, G. J. and Chanton, J. P.: Control of diurnal pattern of methane emission from aquatic macrophytes by gas transport mechanisms, Aquat. Bot., 54, 237-253, 1996.

Whiting, G. J. and Chanton, J. P.: Greenhouse carbon balance of wetlands: methane emission versus carbon sequestration, Tellus B, 53, 521-528, 2001.

Wickland, K.: Carbon gas exchange at a southern Rocky Mountain wetland, 1996-1998, Global Biogeochem. Cy., 15, 321-335, 2001.

Wilson, D., Tuittila, E.-S., Alm, J., Laine, J., Farrell, E. P., and Byrne, K. A.: Carbon dioxide dynamics of a restored maritime peatland, Ecoscience, 14, 71-80, 2007.

Wilson, D., Alm, J., Laine, J., Byrne, K. A., Farrell, E. P., and Tuittila, E.-S.: Rewetting of cutaway peatlands: are we re-creating hot spots of methane emissions?, Restor. Ecol., 17, 796-806, doi:10.1111/j.1526-100X.2008.00416.x, 2009.

Wilson, D., Farrell, C., Mueller, C., Hepp, S., and Renou-Wilson, F.: Rewetted industrial cutaway peatlands in western Ireland: a prime location for climate change mitigation?, MaP, 11, 1-22, 2013.

Yli-Petäys, M., Laine, J., Vasander, H., and Tuittila, E.-S.: Carbon gas exchange of a revegetated cut-away peatland five decades after abandonment, Boreal Environ. Res., 12, 177-190, 2007.

Zak, D., Reuter, H., Augustin, J., Shatwell, T., Barth, M., Gelbrecht, J., and McInnes, R. J.: Changes of the $\mathrm{CO}_{2}$ and $\mathrm{CH}_{4}$ production potential of rewetted fens in the perspective of temporal vegetation shifts, Biogeosciences, 12, 2455-2468, doi:10.5194/bg-122455-2015, 2015.

Zar, J. H.: Biostatistical Analysis, Prentice Hall, Upper Saddler River, 1999.

Zhou, L., Zhou, G., and Jia, Q.: Annual cycle of $\mathrm{CO}_{2}$ exchange over a reed (Phragmites australis) wetland in Northeast China, Aquat. Bot., 91, 91-98, 2009. 